\title{
EVALUATION OF THE EFFECTS OF COLD ATMOSPHERIC PLASMA AND PLASMA-TREATED LIQUIDS IN CANCER CELL CULTURES
}

Juan Tornin ${ }^{1,2,3,4}$, Cédric Labay ${ }^{1,2,3}$, Francesco Tampieri ${ }^{1,2,3}$, Maria-Pau Ginebra ${ }^{1,2,3,5}$ and Cristina Canal $^{1,2,3 \S}$

${ }^{1}$ Biomaterials, Biomechanics and Tissue Engineering Group, Department of Materials Science and Engineering (CEM), Universitat Politècnica de Catalunya (UPC-BarcelonaTECH), Escola d'Enginyeria Barcelona Est (EEBE), c/ Eduard Maristany 14, 08019 Barcelona, Spain.

${ }^{2}$ Barcelona Research Center in Multiscale Science and Engineering, UPC, Spain.

${ }^{3}$ Research Center in Biomedical Engineering (CREB), UPC, Spain

${ }^{4}$ Instituto de Investigación Sanitaria del Principado de Asturias (ISPA), Av. de Roma s/n, Oviedo, Spain.

${ }^{5}$ Institute for Bioengineering of Catalonia (IBEC), Barcelona Institute of Science and Technology (BIST), c/ Baldiri i Reixach 10-12, 08028 Barcelona, Spain

\section{(§) Correspondence should be addressed to:}

Cristina Canal, $\mathrm{PhD}$

Biomaterials, Biomechanics and Tissue Engineering Group, Dpt. Materials Science and Engineering, Universitat Politècnica de Catalunya (UPC-BarcelonaTECH), Escola d'Enginyeria Barcelona Est (EEBE), c/ Eduard Maristany 14, 08019 Barcelona, Spain

Phone: 0034934017810

Email: cristina.canal@upc.edu

Keywords : cold atmospheric plasma ; plasma conditioned liquids ; biological evaluation ; cancer therapy ; cytotoxicity ; molecular markers ; scalability ; reactive oxygen species; reactive nitrogen species;

1 EDITORIAL SUMMARY This protocol describes how to treat cancer cells in culture directly with

2 Cold Atmospheric Plasma or indirectly with Plasma Conditioned Medium. Quantification of the 3 reactive oxygen species present following treatment is described. Upscaling of the treatments to allow 4 molecular biology assays is also described. 
TWEET Quantifying the anti-cancer effects of cold atmospheric plasma \& plasma conditioned medium in cancer cell lines @ERCAPACHE \#plasmamedicine.

COVER TEASER Anti-cancer effects of cold atmospheric plasma

\section{RELATED LINKS}

Key reference(s) using this protocol

Tornin, J. et al. Sci. Rep. 9, 10681 (2019) [doi:10.1038/s41598-019-47128-1]

Mateu-Sanz, M. et al. Cancers 12, 227 (2020) [https://doi.org/10.3390/cancers12010227]

Tornin, J. et al. Free Rad. J Biol. Med. 164, 107 (2021)

[https://doi.org/10.1016/j.freeradbiomed.2020.12.437]

\section{ABSTRACT}

Cold Atmospheric Plasma (CAP) is a potential anti-cancer therapy. CAP has cytotoxic effects when applied either directly to cancer cell cultures or indirectly through plasmaconditioned liquids. This protocol describes how to treat adherent cultures of human cancer cell lines with CAP or Plasma Conditioned Medium (PCM) and determine cell viability following treatment. The protocol also includes details on how to quantify the Reactive Oxygen and Nitrogen Species (RONS) present in medium following CAP treatment, using chemical probes using UV-visible or fluorescence spectroscopy. CAP treatment takes approximately $30 \mathrm{~min}$, and 3 hours are required to complete quantification of RONS. By providing a standardized protocol for evaluation of the effects of CAP and PCM we hope to facilitate the comparison and interpretation of results seen across different laboratories.

\section{INTRODUCTION}

There are four fundamental states of matter: solid, liquid, gas and plasma. When a gas is subjected to an electrical discharge it becomes totally or partially ionized and, in this state, is named plasma. Plasma includes photons (as ultraviolet (UV) or visible radiation), electromagnetic fields, electrons, ions and neutral radicals such as Reactive Oxygen and Nitrogen Species (RONS). Cold Atmospheric Plasma (CAP) operates at ambient pressure and temperatures below $40^{\circ} \mathrm{C}$, thus can be applied to living tissues or cell cultures. Cold plasma is used clinically, for example in sterilization or decontamination to remove bacteria ${ }^{1-4}$, wound healing ${ }^{5-7}$, blood coagulation ${ }^{5,8}$, and in clinical devices developed to eliminate skin infections or tumors ${ }^{9-11}$.

CAP has also been proposed as a selective anti-cancer therapy in a growing number of papers, reviewed in ${ }^{12}$. However, the anti-tumor selectivity depends on the concentration of RONS 
generated by $\mathrm{CAP}^{13}$. CAP produces a large number of both short- and long- lived RONS, which impact living cells by increasing the amount of oxidative stress they are subjected to. However, because all cells are sensitive to oxidative stress it is currently unclear how universally selective $\mathrm{CAP}$ is to cancer cells compared to normal cells. Some of the effects seen might be a consequence of the experimental setting in which they were applied ${ }^{14,15}$.

In this protocol we therefore provide a detailed protocol to facilitate standardized evaluation of the effects of CAP on cancer cells growing in culture. We have previously used this protocol in multiple primary research papers evaluating the effect of CAP on cancer and healthy cell cultures, showing that application parameters and formulation of culture media modify the concentration of RONS and the cytotoxic potential of CAP ${ }^{14,16-18}$.

\section{CAP as an anti-cancer treatment}

Different devices have been developed that apply an electrical discharge, thus ionizing gas to plasma. The protocol uses plasma jets to generate plasma. The interaction of the plasma gas phase with a liquid phase, generates a variable amount of RONS depending on the device parameters ${ }^{14,19}$. Helium alone has been the most-used carrier gas (35.8\%), followed by air (26.3\%) and argon $(22.1 \%)^{12}$.

Parameters that influence plasma application, such as the distance from the tip of the plasma jet (jet nozzle) to the liquid surface, composition of the gas (pure or gas mixture), treatment time or gas flow greatly modify the cellular response, mainly by tuning the RONS generated ${ }^{15}$. For this reason, the parameters by which plasma is applied have a considerable impact on whether anticancer activity occurs. It is thus important that standardized protocols are available that describe how to evaluate the effects of CAP on cancer cells to allow comparison of assays undertaken in different laboratories.

According to the review of Dubuc A. et al., most studies to date have been conducted in vitro $(94.7 \%)$ with only $14.2 \%$ looking at the effect of CAP in vivo ${ }^{12}$. Nevertheless, clinical trials are ongoing and are described in $1.6 \%$ of the studies ${ }^{12}$. Many different experimental setups have been used in the in vitro studies which can make comparison of results difficult as even small differences, such as the cell culture media employed ${ }^{14}$, can lead to huge differences in results obtained. The impact of modifications to operational parameters such as type of gas, gas flow, distance of the plasma nozzle or different biochemical compositions of the liquid cold plasmas are summarized in Supplementary Table 1. 


\section{Types of CAP}

In this protocol we describe how to use the two main types of cold atmospheric plasma treatments that are described and used in the field of Plasma Medicine. This enables the effect of exposure to all components of plasma (direct treatment) to be compared with the effects of RONS generated by plasma in cell culture media (Indirect treatment).

In direct Treatment, herein designated as CAP, He plasma jet is located right above the surface of the cell culture, leaving a cell culture medium interface between the cells and the plasma jet (Figure 1, left). In this treatment, all plasma components can act over all the cells if the plasma jet, the working conditions and the voltage are applied correctly. Thus, the cells are exposed to electromagnetic fields, ultraviolet light and ions, in addition to the reactive species generated by plasma and the de novo reactive species generated by the plasma in contact with the macromolecules and ions present in the cell culture medium.

In indirect Treatment, herein designated as Plasma Conditioned Medium (PCM), the plasma jet is not positioned close to the cell culture. Instead, CAP is applied to treat a liquid, which results in the formation of new reactive species in the liquid. This liquid treated with plasma has been described in the literature as Plasma-treated liquid, Plasma-Activated Liquid (PAL), or PCM if the liquid treated is a cell culture medium. The cells are then cultured in the presence of PCM. In this setting cells are exposed only to the RONS, ions and stable active molecules that have been generated in the PCM, and are not exposed to any ultraviolet light or electromagnetic fields generated during production of plasma. The actual RONS generated in PCM vary and are influenced by the physical parameters applied during plasma treatment and the composition of the medium, as discussed later.

To date cold-plasma has been predominantly applied to monolayer cultures of adherent cancer cells. Direct CAP cannot be homogeneously applied to large cell culture areas or deep tissues. The effects of plasma generated RONS have been predominantly evaluated using PCM ${ }^{20,21}$. Both PCM and PAL only contain the long-lived RONS produced by diffusion or RONS produced following secondary reactions initiated by plasma in the liquid.

Previously, the results obtained from cytotoxicity assays have usually been correlated to the concentration of long-lived RONS, mainly $\mathrm{NO}_{2}{ }^{-}$or $\mathrm{H}_{2} \mathrm{O}_{2}{ }^{19,22}$. However, the concentration of RONS varies based on the type of application of CAP, time, cell surface, well-plate, volume of liquid, biochemical composition of the sample and many other parameters ${ }^{19}$. The small size of the plasma jets used in biomedical applications limit the number of cells that can be directly treated with CAP, thus researchers often have to instead employ PCM to describe the signaling pathways affected by $\mathrm{CAP}^{14,23}$. The complexity of the components of the plasma and the reactive species generated by the different plasma devices in the liquids, and the variety of experimental 
settings limit comparison of data from different laboratories. Thus, the contribution of all plasma components (CAP) and an understanding of which components mediate particular biological effects remain poorly understood. The use of a protocol able to compare CAP and PCM jets under the same experimental design that is compatible with basic molecular biology assays facilitates study of the full effect of CAP on cells.

\section{Experimental Design}

This protocol covers the entire procedure required to investigate cell signaling in cells exposed either to all Cold Plasma components (CAP) or to Plasma generated RONS in cell culture media (PCM). Figure 1 overviews the whole procedure. The procedure starts by describing how to set up cell cultures and treat directly with CAP or indirectly with PCM (Figure 2) (steps 1-13). Cytotoxicity is assessed by colorimetric (WST-1 based) metabolic assay (steps 14-21). In the second stage of the procedure the RONS present in treated cell culture medium are assessed using the assays described in steps 22-64. In the final stage of the procedure we describe how to harvest treated cells following treatment for downstream assays (steps 65-72).

CAP and PCM treatment: This protocol is based on the method we have used previously ${ }^{14,16-}$ ${ }^{18}$. We made minor modifications to the protocol during our earlier studies. Initially we analyzed the cytotoxic effect of PCM in 96-well plates ${ }^{14,16}$, but this well size limited our ability to analyze molecular mechanisms. For this reason, here we focus mainly on the use of 24-well plates. However the protocol is adaptable to different well sizes ${ }^{18}$ and the adaptations required are detailed in Box 1. It is important to bear in mind that the lethality of CAP or PCM is cell seeding dependent ${ }^{14,24}$

Furthermore, we recommend the use of a commercial plasma jet (kINPen) used in clinical trials ${ }^{9}$ to allow easier inter-laboratory comparison. Cold Plasma Jets are required for this protocol, which limits the size of the treatment area. We recommend employing PCM treatment (described here as Option B) if larger areas need to be treated homogeneously, as it can be applied successfully in most well plates and cell culture systems. The lethality of CAP or PCM is RONSdependent ${ }^{14,24}$. We previously demonstrated that some classical components of the culture media can act as scavengers of RONS, e.g. FBS ${ }^{18}$ or Sodium Pyruvate ${ }^{14}$. Thus, minor modifications in the PCM, such as the presence of sodium pyruvate, have been demonstrated to substantially modify the cellular response to $\mathrm{PCM}^{14}$. Thus, we propose cells be preconditioned with the same cell culture media prior to PCM or CAP.

As highlighted in previous work ${ }^{14,18}$, variations in the operational parameters of plasmas, such as gas flow, distance or treatment time can impact the results obtained. Thus, it is essential that the 
same experimental setup is employed and that RONS are accurately quantified, as described in

140 the second stage of the procedure.

141 The protocol is not restricted to use on monolayer cultures but can be applied to organotypic 142 cultures or tumors ${ }^{18}$ or to $3 \mathrm{D}$ engineered tumors ${ }^{25}$. Recently, we used this protocol to treat an osteosarcoma organotypic model and monolayer cultures with Plasma Conditioned Ringers Saline, highlighting that this protocol can be applied to differing culture systems and liquids ${ }^{18,25}$. 145 We used this protocol to characterize cell signaling in osteosarcoma cells exposed to $\mathrm{PCM}^{14}$.We recommend a variety of physiologically relevant cell lines are used in every study ${ }^{14,19,21}$.

To date the differential effects of CAP or PCM using the same experimental settings has not been described, however this protocol enables these comparisons to be made.

This protocol uses a higher cell density than others described in the literature and uses a 24-well plate. In a previous work, we demonstrated that an overload of $\mathrm{H}_{2} \mathrm{O}_{2}$ masks the biological effect of other RONS ${ }^{14}$, so for this reason this protocol applies short CAP treatment times (below 120 s), to enable an equilibrated cocktail of $\mathrm{NO}_{2}{ }^{-}$and $\mathrm{H}_{2} \mathrm{O}_{2}$ to be obtained in all conditions studied. $\mathrm{H}_{2} \mathrm{O}_{2}$ and $\mathrm{NO}_{2}$ have previously been demonstrated to produce the cytotoxic effects of CAP ${ }^{22,26,27}$.

Cell lines employed: In steps 1-3 we describe the cell seeding in monolayer cultures. Osteosarcoma cell lines have been investigated including SaOS-2 ${ }^{14,18,25}$, MG-63 ${ }^{18,25}$ and U-2 OS ${ }^{18}$, and we always include non-cancerous tissue derived cell lines, such as Mesenchymal Stem Cells ${ }^{14,16,18}$, or osteoblasts ${ }^{16}$. An improvement in the current protocol with respect to previous papers is the recommendation to use the same cell culture media (e.g. DMEM) for all cell lines which ensures that the RONS generated in PCM and in contact with cells are comparable for all cell lines being compared in a study.

161 Cytotoxicity Assay: In steps 14-21 we describe how to assess viability of cells following treatment using a water-soluble tetrazolium salt-based assay. WST-1 is cleaved to formazan by cellular mitochondrial dehydrogenases and provides a non-radioactive, spectrophotometric quantification of cell proliferation, growth, viability, and chemosensitivity. As the majority of plate readers read 96-well plates, we describe here how to measure absorbance using a 96-well plates. An advantage of using WST-1 is that it does not require harvesting or lysis steps to determine cell viability. However, other methods can be employed to determine cell viability, such as the LDH cytotoxicity assay ${ }^{16}$, or the use of Quant-iT ${ }^{\mathrm{TM}}$ PicoGreen ${ }^{\circledR}$ dsDNA Kit (Invitrogen, cat.no P11496) that we employed to evaluate the effects of PCM in 3D cultures ${ }^{25}$. in the PCM to fully characterize the RONS cells were exposed to. 
173 Steps 22-28 describe how to detect total ROS. 2',7'-dichlorodihydrofluorescein diacetate (DCFH-

174 DA) is generally used for the detection of short-lived species if added during the treatment.

175 However, due to the timing of this protocol, the probe can be added only after the treatment,

176 therefore, only long-lived ROS are detected. Following the two-step reaction described in Figure

177 3a, DCFH-DA is transformed first into 2' '7'-dichlorodihydrofluorescein (DCFH) by reacting with

$178 \mathrm{HO}$ - radicals before being oxidized into 2',7'-dichlorofluorescein (DCF), a fluorescent

179 compound. By detecting DCF through fluorescence spectroscopy, using excitation and emission

180 wavelength of 560 and $590 \mathrm{~nm}$ respectively, it is possible to quantify the relative generation of

181 ROS in the PCM. This enables quantification of the total ROS.

182 Steps 29-40 describe how to detect hydrogen peroxide $\left(\mathrm{H}_{2} \mathrm{O}_{2}\right)$. Hydrogen peroxide detection is

183 based on the fluorescence detection of resorufin, product of the catalytic reaction between $\mathrm{H}_{2} \mathrm{O}_{2}$

184 and Amplex ${ }^{\mathrm{TM}}$ Red, in the presence of Horseradish Peroxidase (HRP) (Figure 3b). Resorufin can

185 be detected using $560 \mathrm{~nm}$ and $590 \mathrm{~nm}$ as excitation and emission wavelengths, respectively.

186 Steps $41-50$ describe how to detect nitrite ions $\left(\mathrm{NO}_{2}{ }^{-}\right)$, via the Griess test ${ }^{28}$, whose reactions, 187 shown in Figure 3c, generate a pink compound with absorption maximum at $540 \mathrm{~nm}$.

188 Steps 51-65 describe detection of nitrate ions $\left(\mathrm{NO}_{3}^{-}\right)$. Detection of nitrate ions is based on the 189 nitration reaction of 2,6-dimethylphenol ${ }^{27}$. Nitrate ions, in a solution of sulfuric acid-water-acetic 190 acid, react with 2,6-dimethylphenol to produce the corresponding 4-nitro-2,6-dimethylphenol that 191 has an absorption maximum at $324 \mathrm{~nm}$ (Figure 3d). 

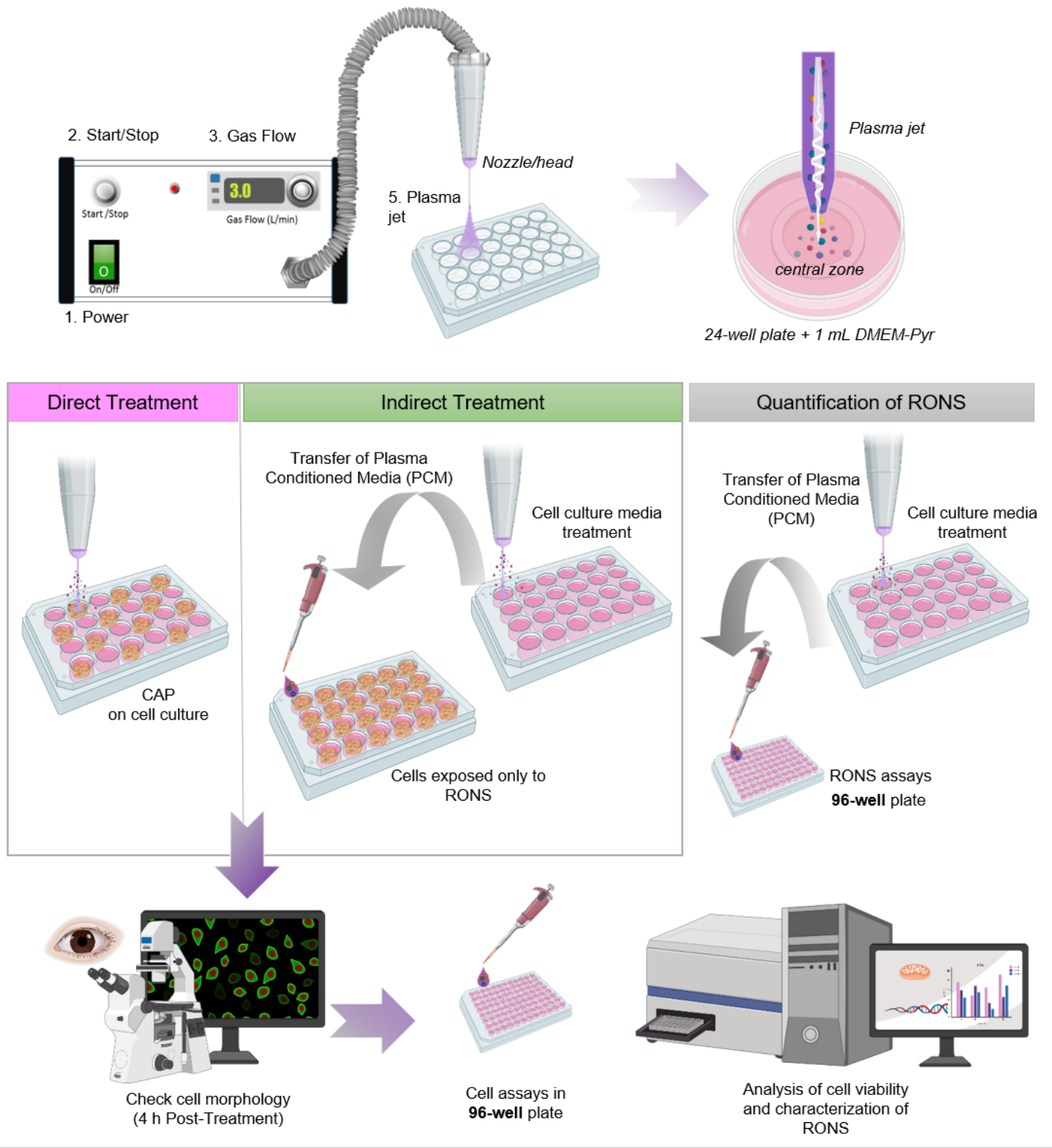

193

Figure 1. Procedure overview. Cells are treated directly by CAP or indirectly with PCM and viability assessed. In parallel, RONS are also quantitated. Created with Biorender ${ }^{\circledR}$. 


\section{Future applications of the protocol}

196 In recent years many researchers have undertaken cell viability tests and characterized the RONS

197 present, and progress has been made towards improving knowledge of the biological mechanisms

198 underlying this technique. However, how CAP or PCM methods affect cell signaling remains

199 poorly understood.

200 The impact of CAP on cell signaling has predominantly been described following PCM treatment,

201 limiting studies to investigating the impact of only the long-lived RONS generated by CAP. The

202 protocol presented here will facilitate investigation of the impact on cell signaling of both direct

203 or indirect CAP treatment. Previous use of 96 well plates has limited the ability of researchers to

204 study the impact of CAP using assays that require a greater number of cells, such as Western Blot

205 or quantitative RT-PCR. This protocol enables a large cell surface area to be treated, which

206 enables a greater number of treated cells to be obtained and an increased number of downstream

207 assays to be applied on these cells.

208 A great advantage of this workflow over other approaches is that the different effects of direct

209 and indirect plasma treatments on RONS generation, cell signaling and cell toxicity can be

210 evaluated using the same experimental settings. The procedure can be adapted for use with any

211 type of Plasma Jet, and we propose wide implementation could improve the reproducibility of the

212 current research. This is particularly important given that in vivo studies and clinical trials using

213 CAP are showing promising results ${ }^{9}$, and efficacy of treatment could be further improved by a

214 greater understanding of the mechanism of action of CAP. 


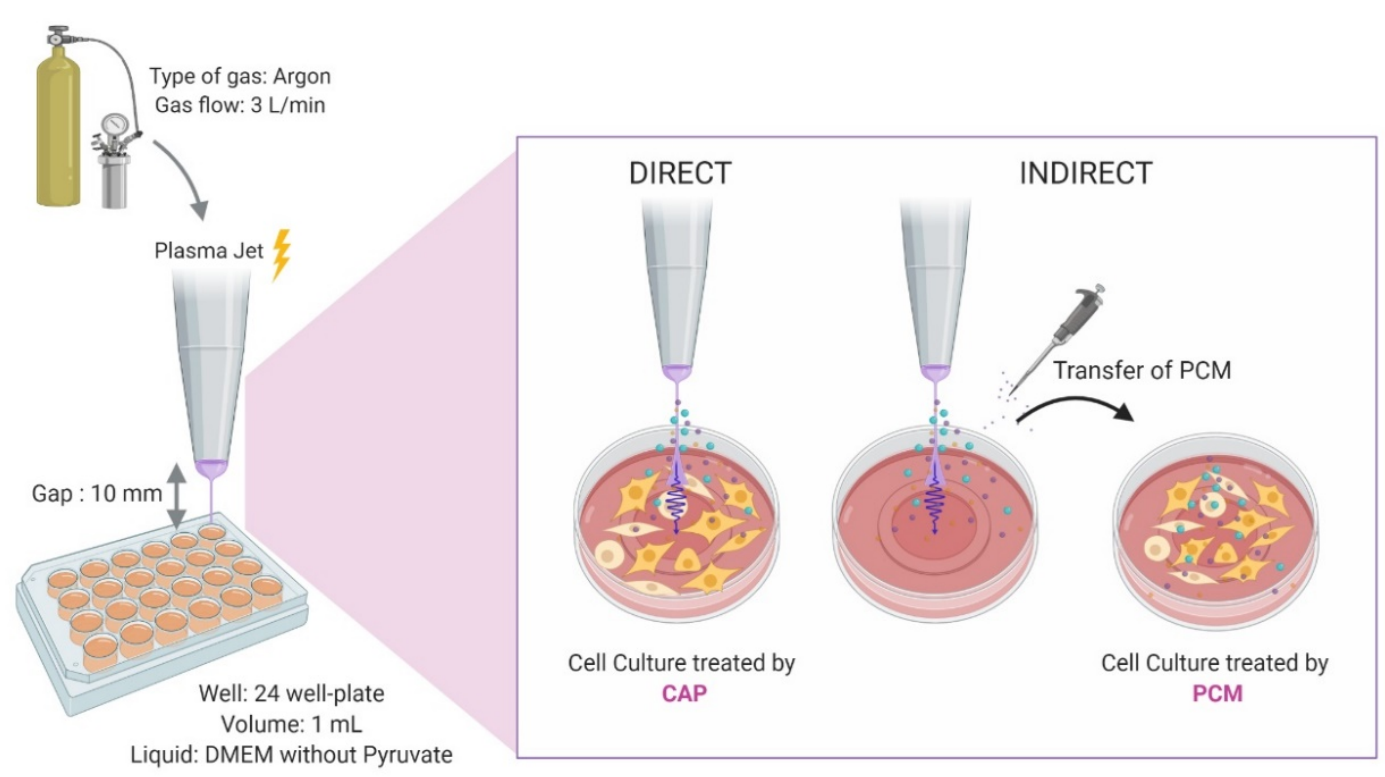

Figure 2. Direct and Indirect treatment can be performed in the same experimental setting. The plasma jet must be placed in a vertical position over the cell culture surface with a constant gap of $10 \mathrm{~mm}$ (distance from the nozzle to liquid surface) and gas flow of $3 \mathrm{~L} / \mathrm{min}$. Each well of the 24-well plate should contain appropriate medium, such as $1 \mathrm{~mL}$ of DMEM without pyruvate. This design allows researchers to compare direct exposure of CAP to indirect treatment (PCM). Created with Biorender ${ }^{\circledR}$.

\section{MATERIALS}

\section{BIOLOGICAL MATERIALS}

220 Cell line: As discussed in the "Experimental design" section", cell lines of various types, have worked well in our experience. The results we show here are from the U-2 OS human osteosarcoma cell line from ATCC (ATCC® HTB-96 ${ }^{\text {TM}}$; RRID:CVCL_0042; https://scicrunch.org/resolver/RRID:CVCL_0042). U-2 OS has epithelial morphology and grows in adherent culture. CAUTION! The cell lines used in your research should be regularly checked to ensure they are authentic and do not contain mycoplasma contamination. We use the MycoAlert ${ }^{\mathrm{TM}}$ Mycoplasma Detection Kit (Lonza, LT07-218) to check our cell lines remain mycoplasma free. CAUTION! Work in a tissue culture hood in a sterile way to avoid crosscontamination by other organisms or cell lines.

\section{REAGENTS}

- Acetic acid (puriss. 99-100\%, Honeywell, cat. 27221, CAS 64-19-7). CAUTION! Acetic acid is flammable and corrosive. Work under chemical hood, use appropriate PPE and keep it distant from heat sources.

- Amplex $^{\mathrm{TM}}$ Red Reagent (Invitrogen ${ }^{\mathrm{TM}}$, cat. no. A12222, CAS 119171-73-2). 
- 2',7'-dichlorodihydrofluorescein diacetate (DCFH-DA, Sigma-Aldrich, cat. no D6883, CAS 4091-99-0).

- 2,6-dimethylphenol (99\%, Aldrich, cat. D175005, CAS 576-26-1). CAUTION! 2,6dimethylphenol is toxic, corrosive and dangerous for the environment, work under chemical hood, use appropriate PPE and dispose it in suitable containers.

- Dimethyl sulfoxide (DMSO, cat. no. 67-68-5; Acros, cat. no. 327182500, CAS 67-685). CAUTION! Dimethyl sulfoxide is irritant and flammable work under chemical hood, use appropriate PPE and keep it distant from heat sources.

- Distilled water.

- DMEM, high glucose, no glutamine, no phenol red (Gibco ${ }^{\mathrm{TM}}$, cat. No. 31053028).

- Dulbecco's PBS without $\mathrm{MgCl}_{2}, \mathrm{CaCl}_{2}$ (DPBS 1x; sterile filtered, suitable for cell culture; BioWest, cat. no. L0615-500 mL).

- Fetal bovine serum, (FBS, Gibco ${ }^{\mathrm{TM}}$, cat. 10270-106)

- Hydrochloric acid 37\% (ACS, ISO, PanReac, cat. 131020.1611, CAS 7647-01-0). CAUTION! Hydrochloric acid is corrosive, work under chemical hood, use appropriate PPE.

- $\quad 30 \%$ hydrogen peroxide solution (Sigma-Aldrich, cat. no. H1009-500ML, CAS 772284-1). CAUTION! Hydrogen peroxide corrosive and a strong oxidizer, work under chemical hood, use appropriate PPE.

- L-glutamine (200 mM) (Gibco ${ }^{\mathrm{TM}}$, cat. no. 25030081, CAS 58-85-9).

- Milli-Q ${ }^{\circledR}$ water (Merck Millipore).

- N-(1-naphtyl)ethylenediamine dihydrochloride (NED) (ACS reagent $>98 \%$, SigmaAldrich, cat. 222488, CAS 1465-25-4). CAUTION! NED is irritant, work under chemical hood, use appropriate PPE.

- Phosphoric acid 85\% (pharma grade, PanReac, cat. 141032.1211, CAS 7664-38-2). CAUTION! Phosphoric acid is corrosive, work under chemical hood, use appropriate PPE.

- Penicillin-Streptomycin $(10,000 \mathrm{U} / \mathrm{mL})\left(\mathrm{Gibco}^{\mathrm{TM}}\right.$, cat. no. 15140122).

- Peroxidase from horseradish, Type VI (HRP) (Sigma-Aldrich, cat. no. P8375, CAS 9003-99-0).

- Potassium nitrate (ReagentPlus ${ }^{\circledR}, \geq 99.0 \%$, Sigma-Aldrich, cat. P8394, CAS 7757-791). CAUTION! Potassium nitrate is an oxidizer, keep it distant from heat sources.

- Sodium hydrogen phosphate heptahydrate $\left(\mathrm{Na}_{2} \mathrm{HPO}_{4} \cdot 7 \mathrm{H}_{2} \mathrm{O}\right)$ (Sigma-Aldrich, cat. no. 7782-85-6, CAS 7782-85-6).

- Sodium hydroxide (ACS, ISO, PanReac, cat. 131687.1211, CAS 1310-73-2). CAUTION! Sodium hydroxide is corrosive, work under chemical hood, use appropriate PPE.

- Sodium dihydrogen phosphate monohydrate $\left(\mathrm{NaH}_{2} \mathrm{PO}_{4} \cdot \mathrm{H}_{2} \mathrm{O}\right)$ (Sigma-Aldrich, cat. no. 10049-21-5, CAS 10049-21-5).

- Sodium nitrite $\left(\mathrm{NaNO}_{2}\right)$ (Sigma-Aldrich, cat. no. 7632-00-0, CAS 7632-00-0) CAUTION! Sodium nitrite is an oxidizer and it is toxic, especially for aquatic organisms, keep it distant from heat sources, use appropriate PPE and dispose it in suitable containers.

- Sulfamic acid (ACS Reagent, Sigma-Aldrich, cat. 383120, CAS 5329-14-6).

- Sulfanilamide ( $\geq 99 \%$, Sigma Aldrich, cat. S9251, CAS 63-74-1).

- Sulfuric acid (ACS, ISO, 95-98\%, PanReac, cat. 471058.1611, CAS 7644-93-9). CAUTION! Sulfuric acid is highly corrosive, work under chemical hood and use appropriate PPE.

- Trypsin-EDTA (0.25\%), phenol red (Gibco ${ }^{\mathrm{TM}}$, cat. no. 25200056).

- WST-1 cell proliferation reagent (CELLPRO-RO Roche, cat. no. 5015944001). 
REAGENT SETUP

\section{Medium for cell culture}

Suitable medium is required for growth of the cell line of interest. We grow U2-OS in Dulbecco's

Modified Eagle Medium (DMEM) supplemented with glucose (4.5 g/L), pyruvate, no glutamine

- 0.5 to $10 \mu \mathrm{L}, 2$ to $20 \mu \mathrm{L}, 10$ to $100 \mu \mathrm{L}, 20$ - to $200 \mu \mathrm{L}$, and 100 to $1,000 \mu \mathrm{L}$ pipets (Eppendorf) with their corresponding sterile tips.

- $\quad-20{ }^{\circ} \mathrm{C}$ Freezer (e.g., Bosch, model no. GSN58AW45).

- $\quad 4{ }^{\circ} \mathrm{C}$ Fridge (e.g., Liebherr, model no. LCV 4010).

- $\quad-80^{\circ} \mathrm{C}$ Freezer (e.g., Eppendorf, Innova U725, model no. U9440-0002).

- Argon entrance line or Argon bottle from (Air Liquide)

- Cell incubator $\mathrm{CO}_{2}\left(95 \%\right.$ humidity, $\left.5 \% \mathrm{CO}_{2}\right)$.

- Centrifuge (Eppendorf), with rotors for Falcon tubes and Eppendorfs.

- Centrifuge tubes (0.5 mL; Eppendorf, cat. no. 211-2140).

- Centrifuge tubes (1.5 mL; Eppendorf, cat. no. 211-2130).

- Hemacytometer.

- Microscope (Nikon).

- Microplate reader for fluorescence measurements equipped with filters for detection of:

- Absorbance measurements at $440 \mathrm{~nm}$ and $540 \mathrm{~nm}$

- Amplex ${ }^{\mathrm{TM}}$ Red: $\lambda_{\mathrm{ex}} \sim 530-560 \mathrm{~nm} / \lambda_{\mathrm{em}} \sim 590 \mathrm{~nm}$

○ DCF: $\lambda_{\text {ex }} \sim 485 \mathrm{~nm} / \lambda_{\mathrm{em}} \sim 528 \mathrm{~nm}$

○ Picogreen: $\lambda_{\text {ex }} \sim 485 \mathrm{~nm} / \lambda_{\text {em }} \sim 528 \mathrm{~nm}$

- Incubator/oven allowing stable $37^{\circ} \mathrm{C}$.

- $\mathrm{pH}$-meter (Crison Instruments).

- Plasma jet kINPen ${ }^{\circledR}$ IND (Neoplas tools GmbH, Greifswald)

- RT-PCR Grade Water (ThermoFisher, cat no AM9935).

- Sterile Falcon tubes (15 mL; VWR, cat. no. 188271).

- Sterile Falcon tubes (50 mL; VWR, cat. no. 227161).

- $\quad 250 \mu \mathrm{L}$ syringe (Hamilton ${ }^{\circledR}$ GASTIGHT ${ }^{\circledR}, 1700$ series)

- $75 \mathrm{~cm}^{2}$ cell culture flasks (T75).

- Ultrapure water system.

- Vortex mixer.

- UV-transparent 96-well plates (Greiner bio-one, UV-Star ${ }^{\circledR}$ )

- Well plates: 96-well plate and dark bottomed 96-well plate, 24-well plate.

\section{SOFTWARE:}

- Microsoft Office Excel 2016 (Microsoft, https://products.office.com/en-us/compare-allmicrosoftoffice-products?activetab=tab\%3aprimaryr1).

- GraphPad Prism 8.0.1. (Gibco ${ }^{\mathrm{TM}}$ cat no. 21969035, Carlsbad, CA, USA), to which we add $10 \%$ fetal bovine serum (FBS) (Gibco $^{\text {TM }}$ cat no. 10270098, Carlsbad, CA, USA), 2 mM L-glutamine (Gibco ${ }^{\mathrm{TM}}$, cat.no 
25030081), 100 units $/ \mathrm{mL}$ penicillin (Gibco ${ }^{\mathrm{TM}}$, cat.no 15140122) and $100 \mu \mathrm{g} / \mathrm{mL}$ streptomycin

330 (Gibco ${ }^{\mathrm{TM}}$, cat.no 15140163$)$. The shelf-life of refrigerated $\left(2^{\circ} \mathrm{C}\right.$ to $\left.8^{\circ} \mathrm{C}\right)$ DMEM supplemented

331 with serum is of 3 to 4 weeks .

WST-1 (to assess cell viability):

333 Upon arrival thaw WST-1 vial to make aliquots of $400 \mu \mathrm{L}$. Store at $-20{ }^{\circ} \mathrm{C}$. CAUTION! If 334 precipitates or turbidity are observed upon thawing, warm up the solution to $37^{\circ} \mathrm{C}$ for $2-10 \mathrm{~min}$ 335 and agitate to dissolve the precipitates. Centrifugation is not recommended because the working 336 concentration would decrease.

\section{DCFH-DA solution for detection of total ROS}

338 Prepare $1 \mathrm{~mL}$ of $2 \mathrm{mM}$ DCFH-DA solution by dissolving $0.974 \mathrm{mg}$ in $1 \mathrm{~mL}$ DMSO in an 339 Eppendorf. This solution can be stored at $-20{ }^{\circ} \mathrm{C}$ for up to six months protected from light.

\section{0 mM Amplex ${ }^{\mathrm{TM}}$ Red reagent stock solution for detection of hydrogen peroxide}

341 Thaw one vial of Amplex ${ }^{\mathrm{TM}}$ Red reagent and warm to room temperature. Just prior to use, 342 dissolve $5 \mathrm{mg}$ Amplex ${ }^{\mathrm{TM}}$ Red reagent in $961.5 \mu \mathrm{L}$ DMSO. Aliquot approximately $30 \mu \mathrm{L}$ of the 343 solution in Eppendorf vials. Each vial of Amplex ${ }^{\mathrm{TM}}$ Red reagent is sufficient for approximately 344200 assays, with a final reaction volume of $100 \mu \mathrm{L}$ per assay. Each vial allows to prepare 5 $345 \mathrm{~mL}$ of the working reagent solution. Amplex ${ }^{\mathrm{TM}}$ Red reagent stock solution can be used on the same day or stored at $-20{ }^{\circ} \mathrm{C}$, protected from light.

$250 \mathrm{U} / \mathrm{mL}$ Horseradish Peroxidase (HRP) stock solution for detection of hydrogen peroxide

Prepare $100 \mathrm{~mL}$ of phosphate buffer $0.1 \mathrm{M}, \mathrm{pH} 6$ by dissolving the appropriate amount of sodium hydrogen phosphate heptahydrate $\left(\mathrm{Na}_{2} \mathrm{HPO}_{4} \cdot 7 \mathrm{H}_{2} \mathrm{O}\right)$ and sodium dihydrogen phosphate monohydrate $\left(\mathrm{NaH}_{2} \mathrm{PO}_{4} \cdot \mathrm{H}_{2} \mathrm{O}\right)$ in Milli-Q ${ }^{\circledR}$ water. Check the $\mathrm{pH}$ with a $\mathrm{pH}$-meter and adjust it with small volumes of $1 \mathrm{M} \mathrm{HCl}$ or $\mathrm{NaOH}$ solutions if necessary. Allow the vial of HRP to warm at room temperature for $10 \mathrm{~min}$. Dissolve the content of the vial in phosphate buffer to obtain a final concentration of $250 \mathrm{U}$ of $\mathrm{HRP} / \mathrm{mL}$. The volume of dilution depends on the enzymatic units per $\mathrm{mg}$ in the vial (that may change between one vial to another) and the enzymatic units $(U)$. Vortex the mixture for 1 min. Divide the HRP stock solution into singleuse aliquots and store them frozen at $-20^{\circ} \mathrm{C}$. CAUTION! We recommend making low volume aliquots $(20 \mu \mathrm{L})$ to avoid freeze-thaw cycles. CAUTION! We recommend working with the enzymatic activity of HRP. 
363 Griess reagent (GR) is used for detection of $\mathrm{NO}_{2}^{-}$in PCM. It consists of $1.0 \%$ sulfanilamide, $3640.1 \% \mathrm{~N}-\left(1-\right.$ naphtyl) ethylene diamine (NED) and 3.3\% of phosphoric acid in Milli-Q ${ }^{\circledR}$ water. 365 Mix $1.0 \mathrm{~g}$ of sulfanilamide, $0.1 \mathrm{~g}$ of NED and $2.3 \mathrm{~mL}$ of $85 \%$ phosphoric acid in $100 \mathrm{~mL}$ ultra-

366 pure water. Add a magnetic stirrer to the flask and stir for two hours to obtain a homogeneous 367 solution, keeping the volumetric flask protected from light. Store GR at $-20^{\circ} \mathrm{C}$ in $5 \mathrm{~mL}$ aliquots.

368 When thawed, it is not advised to store GR at $4{ }^{\circ} \mathrm{C}$ for more than 2 weeks.

369 Sulfuric acid/water solution for detection of nitrate ions

370 In a glass bottle (50 or $100 \mathrm{~mL})$ add, using $10 \mathrm{~mL}$ glass pipettes, first $10 \mathrm{~mL}$ of Milli-Q ${ }^{\circledR}$ water, 371 then $30 \mathrm{~mL}$ of concentrated sulphuric acid. Final solution will be $\mathrm{H}_{2} \mathrm{SO}_{4}: \mathrm{H}_{2} \mathrm{O}$ 3:1 v/v. CAUTION! 372 Add first water and then acid to the bottle, not the opposite, in order to avoid a strongly exothermic

373 reaction. This solution can be stored for a long time without specific precautions. 0.01 M solution of 2,6-dimethylphenol in glacial acetic acid for detection of nitrate ions

375 Weight the appropriate amount of 2,6-dimethylphenol and dissolve it in glacial acetic acid to 376 obtain a $0.01 \mathrm{M}$ solution. This solution is stable and can be stored for a long time far from heat sources.

0.1 M solution of sulfamic acid in Milli- $Q^{\circledR}$ water for detection of nitrate ions

379 Weight the appropriate amount of sulfamic acid and dissolve it in Milli-Q ${ }^{\circledR}$ water to obtain a 0.1

380 M solution. Water solutions of sulfamic acid are unstable and slowly hydrolyze to ammonium 381 bisulfate. It is advisable to store the solution at $4{ }^{\circ} \mathrm{C}$ for not more than a month. 
(a) Total ROS detection

DCFH-DA<smiles>COc1cc2c(cc1Cl)[C@H](c1ccccc1C(=O)O)c1cc(Cl)c(OC(C)=O)cc1O2</smiles>

(b) $\mathrm{H}_{2} \mathrm{O}_{2}$ detection
$\mathrm{DCFH}$<smiles>O=C(O)c1ccccc1C1c2cc(Cl)c(O)cc2Oc2cc(O)c(Cl)cc21</smiles>

DCF

(Fluorescent)

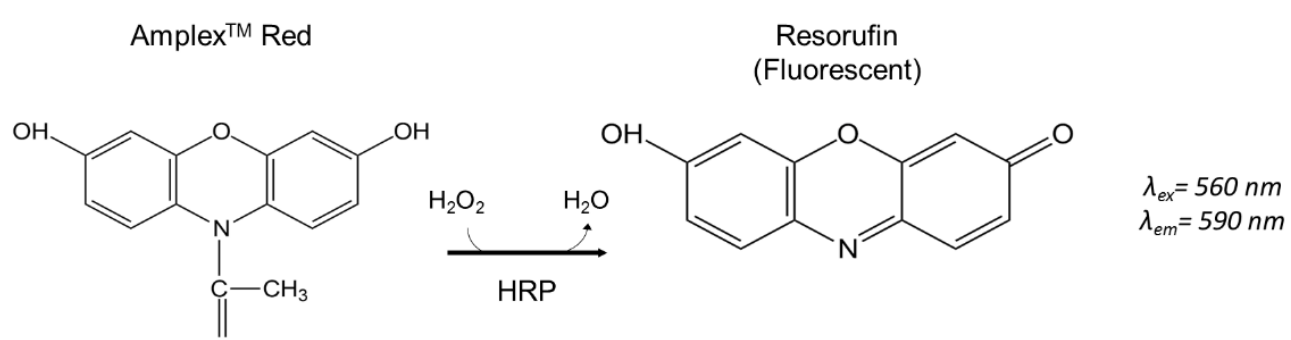

(c) $\mathrm{NO}_{2}$ - detection

Sulfanilamide<smiles>Nc1ccc(S(N)(=O)=O)cc1</smiles>

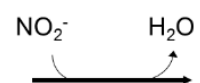<smiles>[CH]C</smiles><smiles>N#[N+]c1ccc(S(N)(=O)=O)cc1</smiles>

6:3:1 $\mathrm{H}_{2} \mathrm{SO}_{4}: \mathrm{H}_{2} \mathrm{O}: \mathrm{AcOH}$<smiles>Cc1cccc(C)c1O</smiles>

$\lambda_{a b s}=267-268 \mathrm{~nm}$<smiles>CCCNc1cccc2ccccc12</smiles>

NED

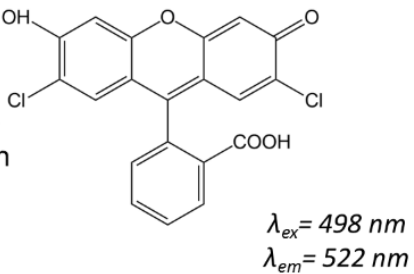

(d) $\mathrm{NO}_{3}-$ detection

384 Figure 3. Chemical reactions used to detect RONS described in this protocol. Principles of the 385 chemical reaction used for the detection of total ROS, $\mathrm{H}_{2} \mathrm{O}_{2}, \mathrm{NO}_{2}{ }^{-}$and $\mathrm{NO}_{3}{ }^{-}$in PCM. (a) total 386 ROS, (b) $\mathrm{H}_{2} \mathrm{O}_{2}$, (c) $\mathrm{NO}_{2}{ }^{-}$and (d) $\mathrm{NO}_{3}{ }^{-}$. 
CRITICAL Prior to commencing the procedure, maintain cell cultures in exponential growth phase in an incubator set at $37{ }^{\circ} \mathrm{C}, 95 \%$ humidity and $5 \% \mathrm{CO}_{2}$ for at least one week. Each cell type must be maintained in its recommended cell culture media prior to CAP treatment. Note that cells should be treated in medium that does not contain Pyruvate (Pyr) however cells can be maintained in medium containing Pyruvate, if appropriate, until $2 \mathrm{~h}$ prior to treatment.

CRITICAL This section describes how to treat cells growing in a 24-well plate. For use of different well sizes or for comparison among different well sizes, follow the scheme in Figure 4.

Cell plating prior to treatment. Time: $60 \mathrm{~min}+$ overnight culture.

1. Trypsinize cells as normal for your cell line and count using a hematocytometer. Plate cells in a 24-well plate at a cell density ranging from 10000 to 30000 cells/well in $1 \mathrm{~mL}$ of cell culture media per well. The cell number seeded depends largely on cell size and proliferation. Please check the cell proliferation of your particular cell line before the experiment and plate accordingly to obtain $70-80 \%$ confluence immediately prior to treatment (i.e. $24 \mathrm{~h}$ after plating). For U-2 OS we usually plate 30000 cells/well for cell viability assessment. For other biological downstream assays we describe seeding later in the procedure. Plate three replicates $(n=3)$ for each condition to be tested and the corresponding untreated controls.

CRITICAL STEP For direct CAP treatment we recommend seeding alternate wells on plates to avoid possible interference of the plasma radiation (electromagnetic field, UVVIS radiation) in cells in adjacent wells during CAP exposure. Leave empty wells around each cultured well.

2. Place the seeded plates in the incubator overnight (for $20 \mathrm{~h}$ total) to allow for adhesion and growth.

Media change. Time: $\mathbf{1 0} \mathbf{m i n}+\mathbf{2} \mathrm{h}$ incubation time.

3. Change cell culture medium by washing once with DPBS and add $1 \mathrm{~mL}$ of DMEM-Pyr to each well. Incubate for $2 \mathrm{~h}$. $30 \mathrm{~min}$ before the end of the incubation time proceed to the next step to prepare for CAP treatment.

CRITICAL STEP Include a cellular control without changing the medium to ensure that lack of Pyr is not affecting cell viability. Troubleshooting.

Cold Plasma Jet Treatment. Time: $\mathbf{4 0 - 4 5}$ min

4. Set the plasma jet and place the plasma jet in a sterile environment, preferably in the sterile culture hood. CRITICAL STEP The plasma jet needs to be turned on $30 \mathrm{~min}$ before performing any treatments. Cells should be kept in the incubator while regulating the plasma parameters.

5. Ensure that the kINPen is connected to the electrical current and to the argon input. Open the argon gas valve.

6. Remove the cap of the kINPen from the head of the jet. CAUTION! Be careful with the ceramic on the head of the jet. Avoid any contact to avoid possible breakage \& contamination. CAUTION! Ensure that the ceramic of the kINPen is clean. Any dirt can modify the characteristics of the plasma discharge. 
7. Place all parts of the equipment in the correct position, as shown in Figure 2. CAUTION! Ensure that the plasma jet is set in vertical position, perpendicular to the worktop. Do not place the kINPen with a tilt angle.

8. Press "ON" to turn on the kINPen. Argon should flow through the kINPen device and power discharge be on. CAUTION! Ensure that kINPen nozzle is not covered by the protecting cap.

9. Set gas flow at $3 \mathrm{~L} / \mathrm{min}$. CAUTION! Ensure that the digital screen units on the kINPen are green. If you are using gas flows above $3 \mathrm{~L} / \mathrm{min}$ or below $1 \mathrm{~L} / \mathrm{min}$, a red color indicates that the kINPen is not working under optimal conditions and can produce overheating.

10. Immediately a thin purple plasma jet should be observed. Allow plasma to stabilize for 10 minutes. Troubleshooting.

11. Adjust the distance of the plasma jet to the well using a 24-well plate containing $1 \mathrm{~mL}$ of water (not a plate containing cells). To do this, remove the lid from the adjustment plate and put the water-containing well below the plasma jet in the center of the well. Set height at $10 \mathrm{~mm}$ of distance between the jet nozzle and the liquid surface (Figure 2). CAUTION! The plasma nozzle should never get wet. To avoid it getting wet, set the plasma jet to a distance higher than $30 \mathrm{~mm}$ prior to adjusting and slowly move closer to $10 \mathrm{~mm}$ (or the desired distance) between jet nozzle and water surface. CRITICAL STEP If you want to use gas flow higher than $3 \mathrm{~L} / \mathrm{min}$, or volumes of liquid higher than $1 \mathrm{~mL}$, do ensure that the tip of the jet does not touch the liquid or that liquid is not spilled out from the jet. Higher gas flows or volumes can expel liquid from the wells. Troubleshooting.

12. Proceed with option A for direct CAP treatment or option B for indirect PCM treatment.

Option A) Direct CAP Treatment

i. Remove cells from the incubator in sterile conditions. At this time point cells will have been in culture for $22 \mathrm{~h}$, with the last $2 \mathrm{~h}$ in DMEM-Pyr.

CRITICAL STEP Ensure this is done at the correct time.

ii. Put the well containing cells to be treated under the plasma jet in operation (at $10 \mathrm{~mm}$ and $3 \mathrm{~L} / \mathrm{min}$ ) for the desired treatment time e.g. 30 seconds. CAUTION! Treatment time must be exactly adhered to.

iii. Once plasma treatment is over, remove the well under the plasma and put the next well under plasma.

iv. After all treatments are finished, press the Stop button and quickly put the lid back on the 24-well plate, to ensure sterile conditions. Place cells back in the cell incubator.

Option B) Indirect PCM treatment

i. Prepare a 24-well plate containing $1 \mathrm{~mL}$ DMEM-Pyr / well for each well in the cell culture plate that will be treated.

ii. Put each well of the plate containing media to be treated under the plasma jet in operation (at $10 \mathrm{~mm}$ and $3 \mathrm{~L} / \mathrm{min}$ ) for the desired treatment time e.g. 30 seconds. CAUTION! Treatment time must be exactly adhered to.

iii. Once plasma treatment is over, remove the well under the plasma and put the next well under plasma, until all wells contain PCM.

CAUTION! CAP should never be used to treat cell-seeded wells in this method.

iv. Place the lid on the plate containing PCM and place in the cell culture hood. 
v. Transfer cells from the incubator to the cell culture hood. Remove and discard cell culture medium from each well containing cells and replace with $1 \mathrm{~mL}$ per well of PCM. CRITICAL STEP Transfer PCM to a seeded 24-well plate as quickly as possible. We recommend avoiding delays above 10 min between plasma treatment and transfer of PCM to the cells. Thus, if long plasma treatment times are being used, we recommend reducing the number of wells treated in step iii prior to carrying out step iv, and then going back to carry out step iii and step iv on the additional wells immediately after. CRITICAL STEP We recommend each well of cells be without media for less than $30 \mathrm{~s}$.

vi. Place the cells in PCM back in the incubator.

13. After four hours in the incubator, check the cells under the optical microscope to observe possible lethal effects, and differences among wells with different treatment times. Check that the untreated cells in DMEM-Pyr are not affected. If that occurs, the cell culture media should be changed in future experiments. Continue to incubate cells and proceed to the assessment of cell viability (step 14) at the required time points.

CRITICAL STEP CAP and PCM treatment time affect the outcomes of the treatment. CAP and PCM can be highly cytotoxic immediately in a cell type dependent manner. Thus effects can be seen on cell morphology by microscopy $4 \mathrm{~h}$ post-treatment. Shorter treatment times can reduce cytotoxic effects. 


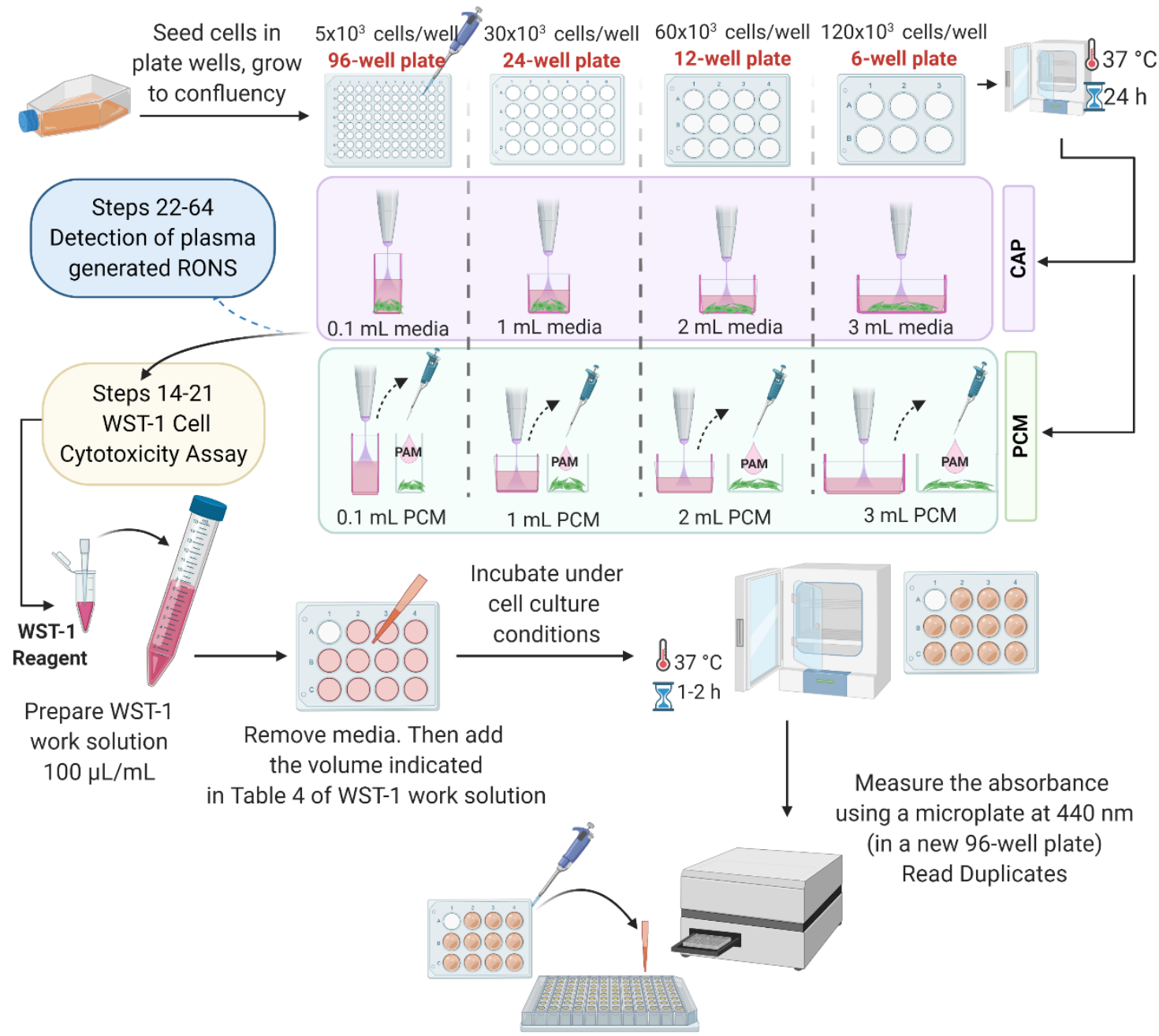

496 Figure 4. Overview of how to use different sizes of dish for CAP and PCM treatments. The 497 adaptations required for different well plate sizes are shown. Only measurement of WST-1 498 activity and RONS detection requires use of a 96-well plate.

ASSESSMENT OF CELL VIABILITY Time: $1.5-3 \mathrm{~h}$, depending on incubation time.

501 CRITICAL We recommend this test be carried out on separate plates if measuring cell viability 502 at different time points following CAP treatment (ie. 24h, 48h, etc.). Perform independent 503 triplicates for each time point.

504 14. Completely thaw a WST-1 aliquot to RT $\left(22{ }^{\circ} \mathrm{C}\right)$ in a cell culture hood in sterile

15. After $24 \mathrm{~h}$ (or more if cell viability is to be measured at different times), remove plasmatreated cultured cells from the cell incubator. 
16. Prepare a working solution of $100 \mu \mathrm{L} / \mathrm{mL}$ WST-1 in DMEM-Pyr (no Phenol Red). Prepare sufficient solution to be able to apply $220 \mu \mathrm{L}$ to each treated well and the untreated control and blank empty wells.

17. Remove and discard the plasma-treated DMEM from each well of the plasma-treated cells (including the untreated wells), wash cells once with $300 \mu \mathrm{L}$ DPBS (pH 7.4) at room temperature (RT, $\left.22^{\circ} \mathrm{C}\right)$. Discard DPBS. Troubleshooting

18. Quickly add $220 \mu \mathrm{L} /$ well of working solution of WST-1 $100 \mu \mathrm{L} / \mathrm{mL}$ to each well of the plate. Add $220 \mu \mathrm{L}$ of working solution to one well without cells so this can be a blank control. Incubate the cells for $1-2 \mathrm{~h}$ in a humidified atmosphere (e.g., $37{ }^{\circ} \mathrm{C}, 5 \% \mathrm{CO}_{2}$ ). CAUTION! The appropriate incubation time after the addition of the WST-1 is cell type dependent. Therefore, it is recommended to do a preliminary experiment to measure the absorption repeatedly at different time points after the addition of the cell proliferation reagent WST-1 (e.g., 0.5, 1, 2, and $4 \mathrm{~h}$ ).

19. When the WST-1 colorimetric reaction is over, remove WST-1 working solution in contact with cells. For each well, place $2 \times 100 \mu \mathrm{L}$ aliquots into separate wells of a 96well plate to enable duplicate readings to be taken. CRITICAL STEP Use 96 well plates with a clear bottom.

20. Measure the absorbance of the samples using a microplate reader at $440 \mathrm{~nm}$. The WST1 working solution in the well without cells should be used as the blank control.

21. Save raw data and calculate relative cell viability of each replicate using the equation below. We undertake this analysis in Microsoft Excel@. Troubleshooting

$$
\text { Relative Cell Viability }=\frac{\text { Abs. average }(\mathrm{n}=2) \text { of sample }- \text { Abs. blank }}{\text { Abs. average }(\mathrm{n}=2) \text { of control }- \text { Abs. blank }}
$$

\section{DETECTION OF PLASMA GENERATED RONS}

CRITICAL Total ROS, $\mathrm{H}_{2} \mathrm{O}_{2}, \mathrm{NO}_{2}{ }^{-}$and $\mathrm{NO}_{3}{ }^{-}$can be quantified at different times from PCM obtained by following Step 12 Option B) i -iii. We recommend first obtaining the total ROS measurement and then measuring the long-lived species, first $\mathrm{H}_{2} \mathrm{O}_{2}$ and then $\mathrm{NO}_{2}{ }^{-}$and $\mathrm{NO}_{3}{ }^{-}$. Keep PCM at $37^{\circ} \mathrm{C}$ between the different stages, save all raw data in the computer from each stage, and finally analyze data when all stages have been finished. In these conditions -with medium buffered at $\mathrm{pH}=7$ - the mentioned RONS are stable, but it is always recommended to start the quantification of RONS in a maximum timeframe of $15 \mathrm{~min}$ after generation of PCM. CRITICAL STEP! Measurement of RONS must be performed in PCM obtained using the same experimental settings (gas flow, liquid volume, time etc.) as those applied for CAP treatment of cell cultures.

Total ROS in Plasma Conditioned Media. 45 min plus PCM production

CRITICAL The following steps describe the total ROS assay in a total volume of $\sim 150 \mu \mathrm{L}$ per well (96-well dark bottomed plates).

22. Thaw the $2 \mathrm{mM}$ DCHF-DA aliquot at room temperature protected from light before starting.

23. Collect $150 \mu \mathrm{L}$ of PCM from each well of $1 \mathrm{~mL}$ plasma-treated media (generated as described in Step 12 Option B i - iii in a black 96-well plate. Also prepare a well containing $150 \mu \mathrm{L}$ that can be used as an untreated control. 
24. Add $1 \mu \mathrm{L}$ of $2 \mathrm{mM}$ DCHF-DA to each well with PCM and the untreated medium as control. The final concentration of DCHF-DA after the addition will be $13 \mu \mathrm{M}$.

25. Incubate for $30 \mathrm{~min}$ protected from light at room temperature.

26. Read fluorescence intensity using a microplate reader at $\lambda_{\mathrm{ex}}=485 \mathrm{~nm}$ and $\lambda_{\mathrm{em}}=528 \mathrm{~nm}$. Troubleshooting.

27. Repeat steps 23 to 26 twice to obtain three independent replicates.

28. Save raw data and normalize data as relative fluorescence intensity with respect to the untreated medium. We undertake this analysis in Microsoft Excel $\odot$.

$$
\text { ROS intensity }=\frac{\text { Fluorescence sample }}{\text { Fluoresence control }}
$$

CRITICAL STEP Note that short lived ROS quickly disappearing from the PCM cannot be quantified by this method.

Detection of Hydrogen Peroxide 75 min plus PCM production

CRITICAL The following steps describe the $\mathrm{H}_{2} \mathrm{O}_{2}$ assay in a total volume of $100 \mu \mathrm{L}$ per well (96well dark bottomed plates).

29. Thaw $50 \mu \mathrm{L}$ of $20 \mathrm{mM}$ Amplex ${ }^{\mathrm{TM}}$ Red reagent stock solution and $10 \mu \mathrm{L}$ of $250 \mathrm{U} / \mathrm{mL}$ HRP stock solution, at room temperature. CAUTION! Protect aliquots from light.

30. Prepare $5 \mathrm{~mL}$ of Amplex ${ }^{\mathrm{TM}}$ Red reagent and HRP working solution, $100 \mu \mathrm{M}$ and 0.25 $\mathrm{U} / \mathrm{mL}$, respectively, by mixing the following compounds (for 200 assays) (See Figure 4): $25 \mu \mathrm{L}$ of $20 \mathrm{mM}$ Amplex ${ }^{\mathrm{TM}}$ Red reagent stock solution. $5 \mu \mathrm{L}$ of $250 \mathrm{U} / \mathrm{mL}$ HRP stock solution. $4.970 \mathrm{~mL}$ of distilled or Milli-Q water.

31. Prepare a $20 \mathrm{mM}$ standard $\mathrm{H}_{2} \mathrm{O}_{2}$ solution by diluting commercial $30 \%$ solution. Mix 10 $\mu \mathrm{L}$ of $30 \% \mathrm{H}_{2} \mathrm{O}_{2}$ solution $(9.8 \mathrm{M})$ with $4.9 \mathrm{~mL}$ of the corresponding medium, as recommended, here we use DMEM-Pyr.

32. Prepare standard $\mathrm{H}_{2} \mathrm{O}_{2}$ solutions for the calibration line by diluting the appropriate amount of $20 \mathrm{mM} \mathrm{H} \mathrm{H}_{2} \mathrm{O}_{2}$ working solution using cell culture medium. The standard solutions should have concentrations between 0 to $6 \mu \mathrm{M}$, with a volume of at least $150 \mu \mathrm{L}$ for each. Be sure to include a sample without any $\mathrm{H}_{2} \mathrm{O}_{2}(0 \mu \mathrm{M})$. The recommended dilutions to build the calibration line, from D2 to D8, are stated in Table 1. The experimental steps are shown in Figure 5.

Table 1. Recommended dilutions to prepare the $\mathrm{H}_{2} \mathrm{O}_{2}$ standard solutions for the calibration line starting from the $20 \mathrm{mM}$ stock solution.

\begin{tabular}{|c|c|c|c|c|c|c|c|c|c|}
\hline & D0 & D1 & D2 & D3 & D4 & D5 & D6 & D7 & D8 \\
\hline$\left[\mathrm{H}_{2} \mathrm{O}_{2}\right]$ & $400 \mu \mathrm{M}$ & $8 \mu \mathrm{M}$ & $6 \mu \mathrm{M}$ & $4 \mu \mathrm{M}$ & $2 \mu \mathrm{M}$ & $1 \mu \mathrm{M}$ & $0.5 \mu \mathrm{M}$ & $\begin{array}{l}0.25 \\
\mu \mathrm{M}\end{array}$ & $0 \mu \mathrm{M}$ \\
\hline $\begin{array}{l}\text { Volume } \\
\text { picking } \\
\text { solution }\end{array}$ & $\begin{array}{c}20 \mu \mathrm{L} \text { of } \\
\text { Stock } \\
\text { solution }\end{array}$ & $\begin{array}{l}20 \mu \mathrm{L} \\
\text { of D0 }\end{array}$ & $\begin{array}{c}150 \mu \mathrm{L} \\
\text { of } \mathrm{D} 1\end{array}$ & $\begin{array}{c}100 \mu \mathrm{L} \\
\text { of } \mathrm{D} 1\end{array}$ & $\begin{array}{c}100 \mu \mathrm{L} \\
\text { of } \mathrm{D} 3\end{array}$ & $\begin{array}{c}100 \mu \mathrm{L} \\
\text { of } \mathrm{D} 4\end{array}$ & $\begin{array}{c}100 \mu \mathrm{L} \\
\text { of } \mathrm{D} 5\end{array}$ & $\begin{array}{c}100 \mu \mathrm{L} \\
\text { of } \mathrm{D} 6\end{array}$ & $0 \mu \mathrm{L}$ \\
\hline Medium & $980 \mu \mathrm{L}$ & $980 \mu \mathrm{L}$ & $50 \mu \mathrm{L}$ & $100 \mu \mathrm{L}$ & $100 \mu \mathrm{L}$ & $100 \mu \mathrm{L}$ & $100 \mu \mathrm{L}$ & $100 \mu \mathrm{L}$ & $100 \mu \mathrm{L}$ \\
\hline
\end{tabular}


584

\section{5}

$$
\begin{aligned}
& 20 \mathrm{mM} \\
& \mathrm{H}_{2} \mathrm{O}_{2} \text { (Stock solution) }
\end{aligned}
$$

(1)

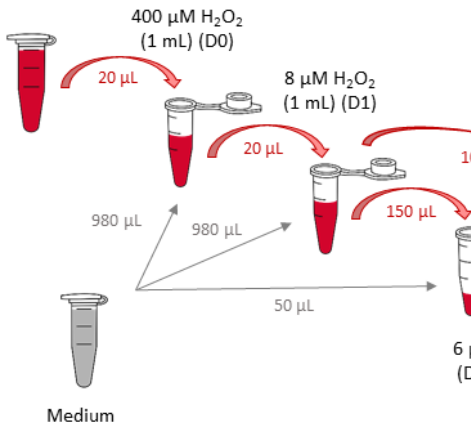

(2)
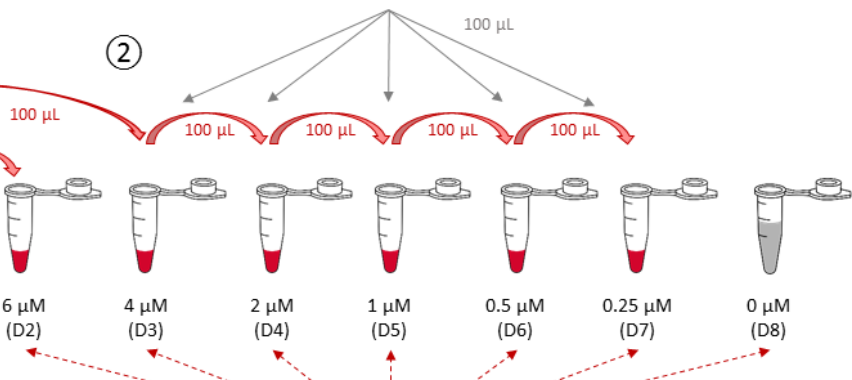

(3)
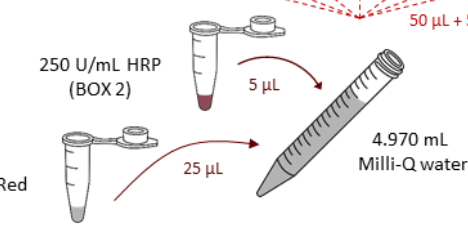

(4)

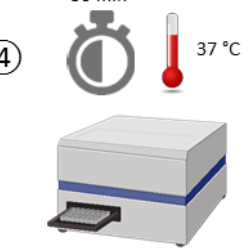

$\lambda_{\mathrm{ex}} 560 \mathrm{~nm} / \lambda_{\mathrm{em}} 590 \mathrm{~nm}$

Figure 5. Experimental steps to generate a calibration curve for detection of $\mathrm{H}_{2} \mathrm{O}_{2}$. Created with Biorender®.

33. Obtain PCM (by repeating Step 12 Option Bi - iii).

34. Dilute PCM in fresh culture media, here we use DMEM-Pyr. CRITICAL STEP! Cell Culture Media contains components that can interact with Amplex ${ }^{\text {TM }}$ Red. For optimal determination of $\mathrm{H}_{2} \mathrm{O}_{2}$, the final concentration must not exceed $5 \mu \mathrm{M}$. Note that the protocol described here works when samples are diluted 1/100 in the corresponding media. Specific dilutions can be undertaken if it is necessary to have the PCM sample diluted in the range of $0-5 \mu \mathrm{M}$ of $\mathrm{H}_{2} \mathrm{O}_{2}$.

35. Put $50 \mu \mathrm{L}$ of diluted PCM samples (1/100 - or required specific dilution) in the wells of a black 96-well plate, adding untreated cell culture medium as background. In adjacent wells of the same black 96-well plate, add $50 \mu \mathrm{L}$ of the standard solutions for the calibration line prepared in steps 30-31.

36. Add $50 \mu \mathrm{L}$ of the Amplex ${ }^{\mathrm{TM}}$ Red reagent/HRP working solution to each dark 96-well plate containing the $\mathrm{H}_{2} \mathrm{O}_{2}$ standard solutions or diluted PCM. CAUTION! If red color is detected immediately after the AR/HRP addition, PCM should be further diluted until no red color is detected. This color indicates that the fluorescent probe is saturated due to use of a $\mathrm{H}_{2} \mathrm{O}_{2}$ concentration that is too high.

37. Incubate at $37{ }^{\circ} \mathrm{C}$ for $30 \mathrm{~min}$, protected from light. CAUTION! Because the AR/HRP assay is based on a continuous reaction, it is important to be consistent in timing between addition of AR/HRP reagent and fluorescence reading of the well plate for all the samples you have to measure.

38. Measure fluorescence using a microplate reader in the range of $\lambda_{\text {ex }}=530-560 \mathrm{~nm}$ with detection at an emission wavelength at $\lambda_{\mathrm{em}} \sim 590 \mathrm{~nm}$. We recommend employing autogain to measure fluorescence, and only comparing fluorescence results with a freshly prepared standard curve. Troubleshooting.

39. Save raw data and determine the $\mathrm{H}_{2} \mathrm{O}_{2}$ concentration in PCM from the calibration line. Correct for background fluorescence by subtracting the value derived from untreated 
liquid diluted in the corresponding medium. We undertake this analysis in Microsoft

616 40. Repeat steps 33 to 39 to obtain independent replicates.

Detection of Nitrites 75 min plus PCM production

619 CRITICAL The following steps describe the Griess Reaction employed to quantify $\mathrm{NO}_{2}{ }^{-}$in a total volume of $100 \mu \mathrm{L}$ per well (96 well-plate).

41. Thaw $10 \mathrm{~mL}$ of Griess Working Solution (see reagent setup) at room temperature

Table 2. Recommended dilutions to prepare the $\mathrm{NO}_{2}^{-}$standard solutions for the calibration line starting from the $14 \mathrm{mM} \mathrm{NO}_{2}{ }^{-}$stock solution.

\begin{tabular}{c|cccccccc}
\multicolumn{2}{c}{ D0 } & D1 & D2 & D3 & D4 & D5 & D6 & D7 \\
\hline$\left[\mathrm{NO}_{2}{ }^{-}\right]$ & $140 \mu \mathrm{M}$ & $70 \mu \mathrm{M}$ & $35 \mu \mathrm{M}$ & $17.5 \mu \mathrm{M}$ & $8.75 \mu \mathrm{M}$ & $\begin{array}{c}4.375 \\
\mu \mathrm{M}\end{array}$ & $\begin{array}{c}2.1875 \\
\mu \mathrm{M}\end{array}$ & $0 \mu \mathrm{M}$ \\
$\begin{array}{c}\text { Volume } \\
\text { picking } \\
\text { solution }\end{array}$ & $\begin{array}{c}10 \mu \mathrm{L} \text { of } \\
\text { Stock } \\
\text { solution }\end{array}$ & $\begin{array}{c}100 \mu \mathrm{L} \\
\text { of D0 }\end{array}$ & $\begin{array}{c}100 \mu \mathrm{L} \\
\text { of } \mathrm{D} 1\end{array}$ & $\begin{array}{c}100 \mu \mathrm{L} \\
\text { of D2 }\end{array}$ & $\begin{array}{c}100 \mu \mathrm{L} \\
\text { of D3 }\end{array}$ & $\begin{array}{c}100 \mu \mathrm{L} \\
\text { of D4 }\end{array}$ & $\begin{array}{c}100 \mu \mathrm{L} \\
\text { of D5 }\end{array}$ & $0 \mu \mathrm{L}$ \\
Medium & $990 \mu \mathrm{L}$ & $100 \mu \mathrm{L}$ & $100 \mu \mathrm{L}$ & $100 \mu \mathrm{L}$ & $100 \mu \mathrm{L}$ & $100 \mu \mathrm{L}$ & $100 \mu \mathrm{L}$ & $100 \mu \mathrm{L}$
\end{tabular}




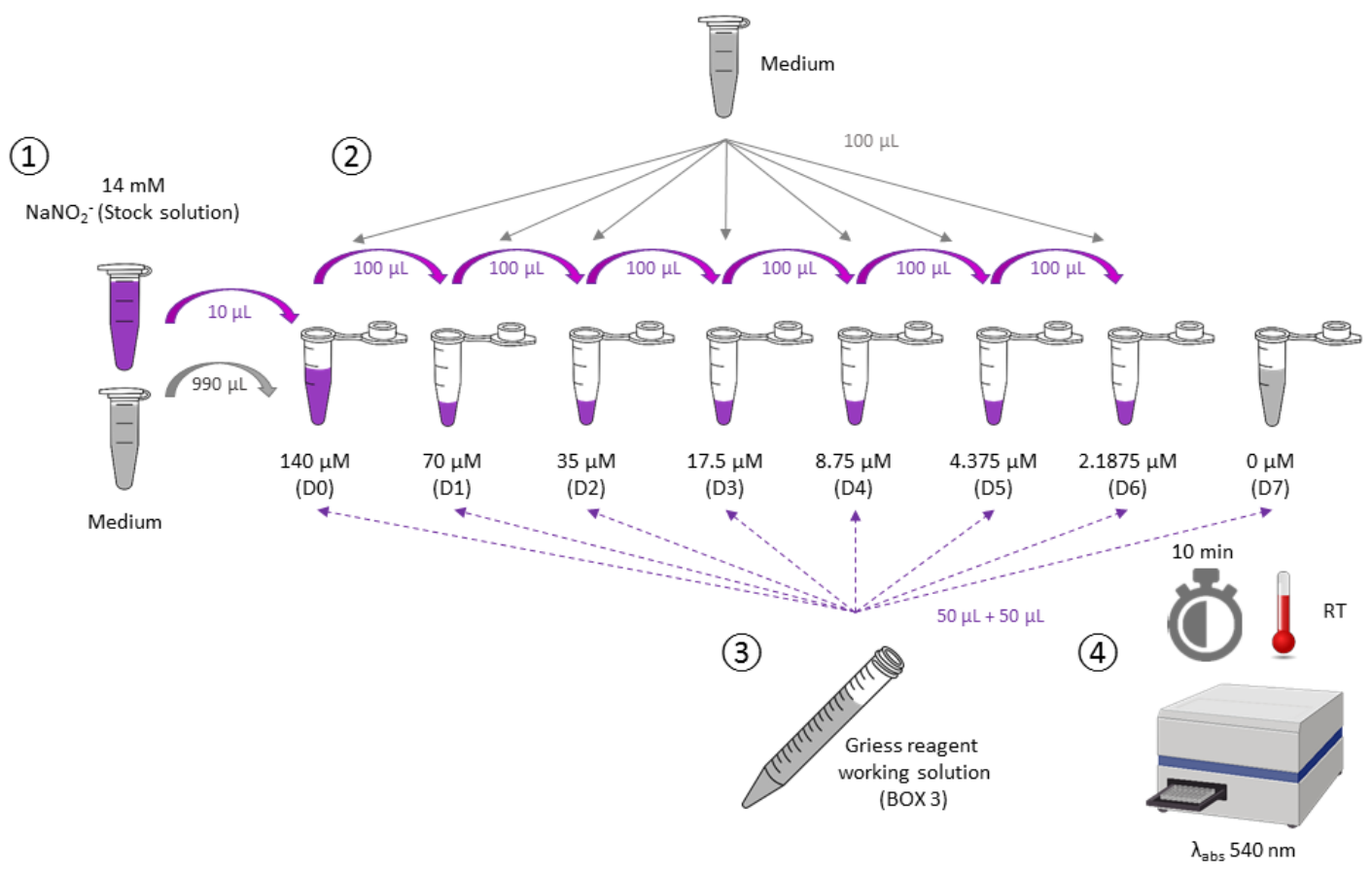

633

634

635

636

637

638

639

640

641

642

643

644

645

646

647

648

649

650

651

652

653

654

655

656

657

658

659

Figure 6. Experimental steps to generate a calibration curve for detection of nitrites. Created with Biorender ${ }^{\circledR}$.

44. Obtain PCM (by repeating steps Step 12 Option B) i - iii.

45. Put $50 \mu \mathrm{L}$ of PCM in the well of a 96 -well plate and add $50 \mu \mathrm{L}$ of the standard solutions for the calibration line (step 43), adding untreated cell culture media as background.

46. Add $50 \mu \mathrm{L}$ of the Griess working solution to each dark 96-well plate containing the standard solutions or PCM.

47. Incubate at room temperature for $10 \mathrm{~min}$, protected from light.

48. Measure absorbance at $540 \mathrm{~nm}$ using a microplate reader.

49. Save the raw data and determine the $\mathrm{NO}_{2}{ }^{-}$concentration in $\mathrm{PCM}$ from the standard curve. Correct for background absorbance by subtracting the value derived from untreated liquid. We use Microsoft Excel $^{\odot}$ to undertake these calculations.

50. Repeat steps 44 to 49 twice to obtain three independent replicates

\section{Detection of Nitrates 75 min plus PCM production}

CRITICAL The following steps describe the method employed to quantify $\mathrm{NO}_{3}{ }^{-}$in a total volume of $125 \mu \mathrm{L}$. The presence of nitrite ions can cause an overestimation of the nitrates concentration. Addition of sulfamic acid (step 54) ensures that all nitrites are removed before the analysis.

51. Prepare a $0.01 \mathrm{M}$ solution of potassium nitrate in in Milli- $\mathrm{Q}^{\circledR}$ by dissolving the appropriate amount of salt in a flask.

52. Prepare $\mathrm{NO}_{3}{ }^{-}$standard solutions for calibration curve. Dilute the appropriate amount of $0.01 \mathrm{M} \mathrm{NO}_{3}{ }^{-}$stock solution using medium to obtain $\mathrm{NO}_{3}{ }^{-}$concentrations between 0 to $400 \mu \mathrm{M}$, with a volume of at least $400 \mu \mathrm{L}$ for each concentration. Be sure to include a sample without any $\mathrm{NO}_{3}^{-}(0 \mu \mathrm{M})$. The recommended dilutions to build the standard curve, from D1 to D7, are stated in Table 3. The experimental steps are shown in Figure 7. 
661 Table 3. Recommended dilutions to build the $\mathrm{NO}_{3}{ }^{-}$calibration curve from the $10 \mathrm{mM} \mathrm{NO}_{3}{ }^{-}$stock 662 solution.

\begin{tabular}{c|cccccccc}
\multicolumn{2}{c}{ D0 } & D1 & D2 & D3 & D4 & D5 & D6 & D7 \\
\hline$\left[\mathrm{NO}_{3}{ }^{-}\right]$ & $1 \mathrm{mM}$ & $400 \mu \mathrm{M}$ & $200 \mu \mathrm{M}$ & $100 \mu \mathrm{M}$ & $50 \mu \mathrm{M}$ & $25 \mu \mathrm{M}$ & $12.5 \mu \mathrm{M}$ & $0 \mu \mathrm{M}$ \\
$\begin{array}{c}\text { Volume } \\
\text { picking }\end{array}$ & $\begin{array}{c}100 \mu \mathrm{L} \\
\text { of stock }\end{array}$ & $\begin{array}{c}400 \mu \mathrm{L} \\
\text { of D0 }\end{array}$ & $\begin{array}{c}500 \mu \mathrm{L} \\
\text { of D1 }\end{array}$ & $\begin{array}{c}500 \mu \mathrm{L} \\
\text { of D2 }\end{array}$ & $\begin{array}{c}500 \mu \mathrm{L} \\
\text { of D3 }\end{array}$ & $\begin{array}{c}500 \mu \mathrm{L} \\
\text { of D4 }\end{array}$ & $\begin{array}{c}500 \mu \mathrm{L} \\
\text { of D5 }\end{array}$ & $0 \mu \mathrm{L}$ \\
solution & solution & & & & & & & \\
Medium & $900 \mu \mathrm{L}$ & $600 \mu \mathrm{L}$ & $500 \mu \mathrm{L}$ & $500 \mu \mathrm{L}$ & $500 \mu \mathrm{L}$ & $500 \mu \mathrm{L}$ & $500 \mu \mathrm{L}$ & $500 \mu \mathrm{L}$
\end{tabular}

663

664

665

666

667

668

669

670

671

672

673

674

675
(1)

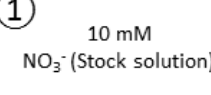
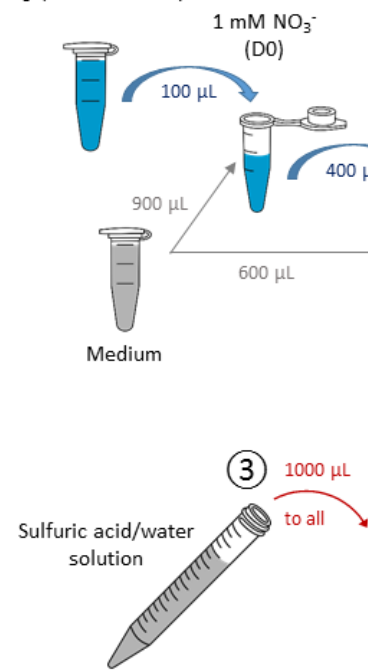

(4) $125 \mu \mathrm{L}$

(2)
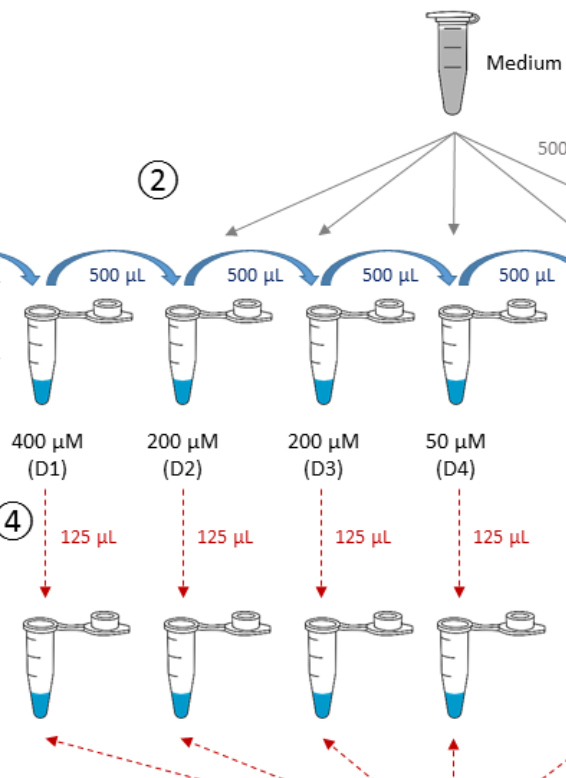

$\begin{array}{lll}\text { (D2) } & \text { (D3) } & \text { (D4) }\end{array}$
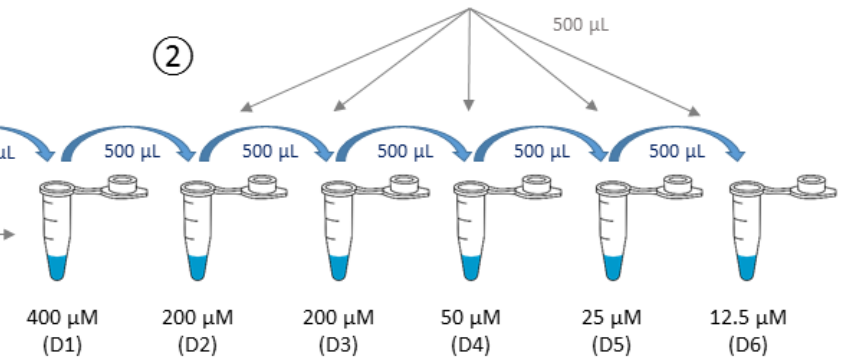

$\begin{array}{ll}\text { (D6) } & 0 \mu \mathrm{M} \\ & \text { (D7) }\end{array}$

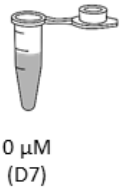

(D5)

$125 \mu \mathrm{L}$

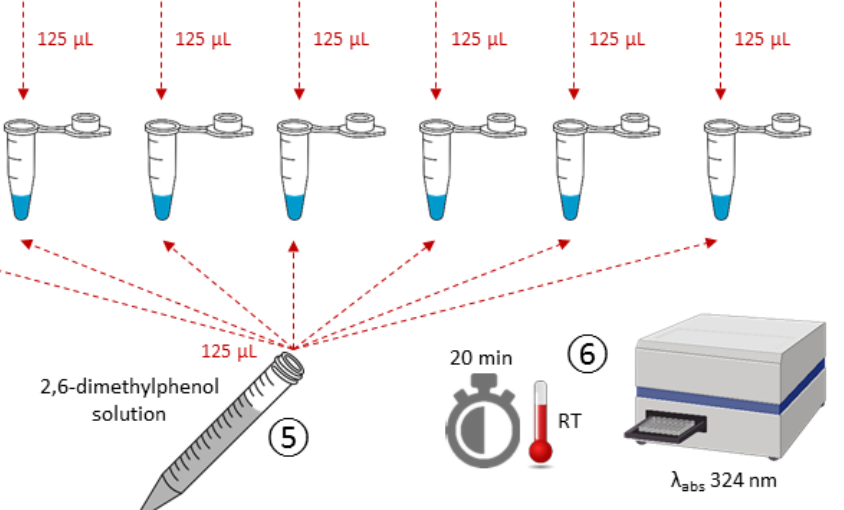

$125 \mu$

Figure 7. Experimental steps to generate a calibration curve for detection of nitrates. Created with Biorender ${ }^{\circledR}$.

53. Obtain PCM (by repeating Steps 12 Option B i - iii).

54. Add $10 \mu \mathrm{L}$ of $0.1 \mathrm{M}$ sulfamic acid solution to each PCM sample.

55. Prepare and label one Eppendorf test tubes for each standard solution and PCM sample.

56. Add $1 \mathrm{~mL}$ of $\mathrm{H}_{2} \mathrm{SO}_{4}: \mathrm{H}_{2} \mathrm{O}$ solution in each Eppendorf tube.

57. Add $0.125 \mathrm{~mL}$ of standard solutions and PCM samples in the corresponding Eppendorf tube.

58. Using a syringe, add $0.125 \mathrm{~mL}$ of $10 \mathrm{mM} 2,6$-dimethylphenol solution in glacial acetic acid to each Eppendorf tube. 
59. Close the Eppendorf tubes and shake to homogenize the solution inside. CAUTION! The reaction is exothermic.

60. Incubate at $25{ }^{\circ} \mathrm{C}$ for $20 \mathrm{~min}$. CAUTION! Since this assay is based on a continuous reaction, it is important to accurately monitor the time between addition of 2,6dimethylphenol and fluorescence reading of the well plate and ensure it is the same for all the samples to be measured.

61. Transfer $0.4 \mathrm{~mL}$ of solution from each Eppendorf tube to a UV-transparent 96-well plate.

62. Record absorbance at $324 \mathrm{~nm}$.

63. Save raw data and plot the absorbance at $324 \mathrm{~nm}$ for the standard $\mathrm{NO}_{3}{ }^{-}$solutions as function of their concentration and obtain the calibration curve.

64. Obtain the $\mathrm{NO}_{3}{ }^{-}$concentration in $\mathrm{PCM}$ samples by the calibration curve. We use

\section{DOWNSTREAM ASSAYS}

\section{Trypsinisation of cells for use in downstream assays}

\section{Time: 30 min}

Critical To obtain a cell pellet with sufficient cells, seed a complete 24-well plate (seed all wells) for each treatment to be analyzed in downstream assays (Supplementary Methods 1).

Critical Note that for some downstream assays, such as use of a Human Phospho-Kinase Array (Supplementary Method 2), trypsinisation should not be used to harvest cells.

66. Remove plasma-treated medium from cells at your preferred time point following step 12

67. Detach cells by adding $200 \mu \mathrm{L}$ trypsin-EDTA to each well. Wait 2-3 minutes at $37^{\circ} \mathrm{C}$.

68. Add $200 \mu \mathrm{L}$ of cell culture media $+10 \%$ FBS to each well to neutralize Trypsin.

69. Collect all cells treated using the same conditions and place in $15 \mathrm{~mL}$ Falcon tubes. and wash each well once with $200 \mu \mathrm{L}$ DPBS (pH 7.4) at RT.

CRITICAL STEP: If you plan to study the mechanisms underlying cell death, such as apoptosis or necrosis, retain the plasma-treated medium and combine it with cells trypsinized in step 68 .

711 71. Discard the cell culture medium and wash the cell pellet with $2 \mathrm{~mL}$ DPBS (pH 7.4) at RT.

712 72. Centrifuge the cells at $150 \mathrm{~g}$ for 5 minutes. 
73. Discard DPBS and proceed to further assays, such as RT-PCR (Supplementary Method

Box 1: PCM Treatment of cells growing in different culture formats.

717 CRITICAL Because the cell culture volume and well size affects the concentration of RONS produced, direct treatment in different culture formats is not described. Moreover, the small size of the plasma jet does not allow to perform direct treatments homogeneously on big well sizes.

1. Obtain PCM as described in Step 12 Option B) i - iii by treating $1 \mathrm{~mL}$ PCM per well of a 24-well plate, repeating sufficient treatments to generate the required volume of PCM required. The table below gives an indication of the volume of PCM required for different tissue culture plates:

\begin{tabular}{|c|c|c|c|}
\hline Dish size & PCM volume $(\mathrm{mL})$ & Growth area $\left(\mathrm{cm}^{2}\right)$ & Cells/dish (number) \\
\hline $75 \mathrm{~cm}^{2}$ flask & 10 & 75 & $1 \times 10^{6}$ \\
\hline $25 \mathrm{~cm}^{2}$ flask & 4 & 25 & $250 \times 10^{3}$ \\
\hline $100 \mathrm{~mm}$ plate & 8 & 56 & $750 \times 10^{3}$ \\
\hline 6 -well plate & 3 & 9.5 & $120 \times 10^{3}$ \\
\hline 12-well plate & 2 & 4 & $60 \times 10^{3}$ \\
\hline 24-well plate & 1 & 2 & $30 \times 10^{3}$ \\
\hline 48-well plate & 0.5 & 1 & $15 \times 10^{3}$ \\
\hline 96-well plate & 0.1 & 0.32 & $5 \times 10^{3}$ \\
\hline
\end{tabular}

2. Combine PCM treated under the same cold plasma conditions in $15 \mathrm{~mL}$ Falcon tubes in sterile conditions.

CRITICAL STEP Do this as quickly as possible. The timing will depend on the time required to produce PCM itself. For example: To obtain $5 \mathrm{~mL}$ of PCM treated for $15 \mathrm{~s}$, it is necessary to treat $15 \mathrm{~s}$ for each $\mathrm{mL}: 15+15+15+15+15=75 \mathrm{~s}$. Do not transfer each $\mathrm{mL}$ separately to the wells; mix them in a falcon tube and then transfer to the well plates as soon as possible. It is recommended not delay this transfer beyond $30 \mathrm{~s}$. CAUTION! Proceed quickly to avoid RONS degradation.

3. Remove cells to be treated from incubator.

734 4. Wash the surface of the cell culture plate with DPBS (pH 7.4) at room temperature.

735 5. Add the volume of PCM indicated in Table 4 to the cells. For example, for the results shown in the Anticipated Results we treated 8 wells, each containing $1 \mathrm{~mL}$ medium, in a 24-well plate, and immediately combined the PCM together in a Falcon tube. We then transferred the $8 \mathrm{~mL}$ of PCM to a $100 \mathrm{~mm}$ plate. 
6. Place the cells with PCM back in the incubator for the required incubation time with PCM.

7. $\quad$ Proceed to further assays.

Table 4. Volumes of components required to adapt the cytotoxicity test to different culture formats.

\begin{tabular}{|c|c|c|c|c|c|c|}
\hline Dish size & $\begin{array}{c}\text { Plate } \\
\text { Cells/well } \\
\text { (number) }\end{array}$ & $\begin{array}{l}\mathrm{V}_{\text {Medium }} \text { for } \\
\text { CAP } \\
\text { treatments } \\
\quad(\mathrm{mL})\end{array}$ & $\mathrm{V}_{\mathrm{PCM}}(\mathrm{mL})$ & $\begin{array}{c}\mathrm{V}_{\text {DPBS }} \text { for } \\
\text { cell } \\
\text { washing } \\
(\mathrm{mL})\end{array}$ & $\begin{array}{c}\text { WST-1 } \\
100 \mu \mathrm{L} / \mathrm{mL} \\
\text { Solution } \\
(\mu \mathrm{L})\end{array}$ & $\begin{array}{c}\mathrm{V}_{\text {WST-1 }} \text { to } \\
\text { read } \\
\text { duplicates } \\
(\mu \mathrm{L})\end{array}$ \\
\hline 96-well plate & $5 \times 10^{3}$ & 0.1 & 0.3 & 0.3 & 110 & $2 \times 50$ \\
\hline 48-well plate & $15 \times 10^{3}$ & 0.5 & 0.6 & 0.6 & 220 & $2 \times 100$ \\
\hline 24-well plate & $30 \times 10^{3}$ & 1 & 1 & 0.6 & 220 & $2 \times 100$ \\
\hline 12-well plate & $60 \times 10^{3}$ & 2 & 2 & 1 & 450 & $2 \times 100$ \\
\hline 6-well plate & $120 \times 10^{3}$ & 3 & 3 & 1 & 900 & $2 \times 100$ \\
\hline
\end{tabular}

\section{TROUBLESHOOTING}

749 See Table 5 for troubleshooting guidance.

Table 5. Troubleshooting.

\begin{tabular}{|c|c|c|ll|}
\hline Step(s) & Issue(s) & Possible reason(s) & \multicolumn{1}{c|}{ Possible solution(s) } \\
\hline 3 & $\begin{array}{c}\text { Cell death observed at } 4 \\
\text { hours }\end{array}$ & $\begin{array}{c}\text { Cell line sensitive to } \\
\text { absence of pyruvate }\end{array}$ & $\begin{array}{l}\text { (I) } \\
\text { Perform a preliminary experiment to } \\
\text { ensure that lack of pyruvate in the cell } \\
\text { culture does not affect cell growth. } \\
\text { Monitor cell growth in the presence or } \\
\text { absence of pyruvate in the cell culture } \\
\text { medium. }\end{array}$ \\
\hline 10 & $\begin{array}{c}\text { kINPen does not turn on } \\
\text { or stabilize }\end{array}$ & $\begin{array}{c}\text { Issue with the } \\
\text { experimental setting of } \\
\text { the plasma device }\end{array}$ & (II) & $\begin{array}{l}\text { Check Argon gas entrance is open, } \\
\text { and gas is flowing correctly. }\end{array}$ \\
& (II) & $\begin{array}{l}\text { Ensure that the mass flow controller is } \\
\text { in operation and the valve is open. } \\
\text { Ensure that the gas entrance tubes are } \\
\text { well connected, and check that the } \\
\text { complete gas circuit does not have } \\
\text { any leaks. }\end{array}$ \\
\end{tabular}




\begin{tabular}{|c|c|c|c|c|}
\hline & & & $\begin{array}{l}\text { (IV) } \\
(\mathrm{V}) \\
(\mathrm{VI})\end{array}$ & $\begin{array}{l}\text { Maintain kINPen in vertical position } \\
\text { with tweezers. } \\
\text { Clean the head of the kINPen with } \\
70 \% \text { ethanol and ensure that the gas is } \\
\text { flowing correctly when plasma is } \\
\text { turned on. } \\
\text { Disassemble the head of the plasma } \\
\text { device and ensure that nothing } \\
\text { obstructs the plasma outlet. }\end{array}$ \\
\hline 11 & $\begin{array}{l}\text { kINPen expelling liquid } \\
\text { from the well }\end{array}$ & $\begin{array}{l}\text { Gas flow is too high or } \\
\text { the working distance } \\
\text { between the plasma } \\
\text { nozzle and liquid/air } \\
\text { interface is too short }\end{array}$ & $\begin{array}{l}\text { (I) } \\
\text { (II) } \\
\text { (III) } \\
\text { (IV) }\end{array}$ & $\begin{array}{l}\text { Ensure that working distance between } \\
\text { liquid surface and plasma nozzle is } 10 \\
\mathrm{~mm} \text {. } \\
\text { Do not use gas flows higher than } 3 \\
\mathrm{~L} / \mathrm{min} \text {. If an experiment requires } \\
\text { higher gas Flow, increase the working } \\
\text { distance. } \\
\text { Check that the volume of liquid inside } \\
\text { the well is } 1 \mathrm{~mL} \text {. } \\
\text { Ensure that the incidence of the } \\
\text { plasma jet is perpendicular to the } \\
\text { central area of the well and that it is } \\
\text { not focusing on the edge of the well. } \\
\text { It should be in the center of the well. }\end{array}$ \\
\hline 14 & $\begin{array}{c}\text { Aliquoted WST-1 is not } \\
\text { homogenous }\end{array}$ & $\begin{array}{l}\text { Stock processing and } \\
\text { storage issue }\end{array}$ & \multicolumn{2}{|c|}{$\begin{array}{l}\text { If the aliquot has a heterogeneous consistency } \\
\text { resuspend by pipetting, or defrost another } \\
\text { aliquot. }\end{array}$} \\
\hline 17 & $\begin{array}{l}\text { Cells detached from the } \\
\text { bottom of the well }\end{array}$ & Lethal dose & & $\begin{array}{l}\text { Shorter treatment time is recommended } \\
\text { Ensure that the volume of cell culture } \\
\text { medium remaining is enough and that } \\
\text { there was not excessive evaporation } \\
\text { from samples. }\end{array}$ \\
\hline 21 & $\begin{array}{l}\text { Lack of data } \\
\text { reproducibility / high } \\
\text { variability in results }\end{array}$ & $\begin{array}{l}\text { Failed to fix } / \text { set the } \\
\text { same plasma setting } \\
\text { conditions. }\end{array}$ & $\begin{array}{l}\text { (I) } \\
\text { (II) } \\
\text { (III) }\end{array}$ & $\begin{array}{l}\text { Maintain constant distance, volume, } \\
\text { treatment time and gas flow between } \\
\text { replicates. Short variations in distance } \\
\text { can lead to big differences in cell } \\
\text { viability and generation of RONS in } \\
\text { PAL or PCM. Therefore, for } \\
\text { optimized reproducibility, we } \\
\text { recommend not moving the plasma } \\
\text { device between different samples to } \\
\text { ensure the same working distance is } \\
\text { maintained. } \\
\text { Ensure that the plasma jet is in } \\
\text { vertical position. } \\
\text { Ensure that the surface of the bench } \\
\text { where the plasma treatments are } \\
\text { performed always remains the same. }\end{array}$ \\
\hline
\end{tabular}




\begin{tabular}{|c|c|c|c|c|}
\hline & & & & $\begin{array}{l}\text { The material the lab bench is made of } \\
\text { can alter the results. If a surface is } \\
\text { metallic we recommend grounding the } \\
\text { bench. The results may vary in the } \\
\text { presence / absence of grounding. }\end{array}$ \\
\hline \multirow[t]{2}{*}{26} & \multirow[t]{2}{*}{$\begin{array}{l}\text { No fluorescence values } \\
\text { recorded }\end{array}$} & $\begin{array}{l}\text { Plate reader working } \\
\text { conditions. }\end{array}$ & (I) & $\begin{array}{l}\text { Ensure that the microplate can collect } \\
\text { the indicated intensity. } \\
\text { Ensure that the parameters of the } \\
\text { microplate are correct (ex. } \\
\text { wavelengths, gain, etc.). }\end{array}$ \\
\hline & & $\begin{array}{l}\text { Degradation of the } \\
\text { reagent }\end{array}$ & $\begin{array}{l}\text { (III) } \\
\text { (IV) }\end{array}$ & $\begin{array}{l}\text { Do not keep the stock solution of the } \\
\text { reagent in presence of light. } \\
\text { Store the stock solution of the reagent } \\
\text { at } 4{ }^{\circ} \mathrm{C} \text { to prevent it from degrading. }\end{array}$ \\
\hline \multirow[t]{2}{*}{38} & \multirow[t]{2}{*}{$\begin{array}{l}\text { Amplex Red }{ }^{\mathrm{TM}} / \mathrm{HPR} \\
\text { method did not work }\end{array}$} & $\begin{array}{l}\text { Production of } \mathrm{H}_{2} \mathrm{O}_{2} \text { was } \\
\text { too high }\end{array}$ & (I) & $\begin{array}{l}\text { If other plasma parameters are used } \\
\text { leading to a possible increase of } \\
\text { hydrogen peroxide production, dilute } \\
\text { the samples in water before adding } \\
\text { AR/HRP reagent to ensure that there } \\
\text { is no saturation of the reaction. } \\
\text { Ensure that the final concentration of } \\
\text { the diluted sample is lower than } 5 \\
\mu \mathrm{M} \text {. }\end{array}$ \\
\hline & & $\begin{array}{l}\text { Plate reader working } \\
\text { conditions. Gain is too } \\
\text { low. }\end{array}$ & (III) & $\begin{array}{l}\text { Use the autogain of the microplate } \\
\text { reader during your first experiment. } \\
\text { Take into account that all the samples } \\
\text { you have to process have to be } \\
\text { measured using the same gain to } \\
\text { allow comparison between them and } \\
\text { manually enter the gain employed by } \\
\text { the plate reader during this } 1 \text { st } \\
\text { experiment for the rest of the } \\
\text { measurement if you are using multiple } \\
\text { well plates. }\end{array}$ \\
\hline
\end{tabular}




\begin{tabular}{|c|c|c|c|c|}
\hline & & $\begin{array}{l}\text { Possible interference } \\
\text { with organic } \\
\text { compounds } \\
\text { Issue with the storage or } \\
\text { the preparation of the } \\
\text { stock or aliquoted } \\
\text { reagent }\end{array}$ & $\begin{array}{l}\text { (IV) } \\
\text { (V) } \\
\text { (VI) }\end{array}$ & $\begin{array}{l}\text { Check that there is no molecule able } \\
\text { to interfere with the AR / HRP } \\
\text { reaction. } \\
\text { If the working solution turned pink, it } \\
\text { indicates a possible contamination of } \\
\text { your reagent. Discard and take } \\
\text { another aliquoted AR and HRP and } \\
\text { prepare a new working solution. } \\
\text { Also check that contamination does } \\
\text { not come from the water used and } \\
\text { ensure that the distilled or MilliQ } \\
\text { water is } \mathrm{H}_{2} \mathrm{O}_{2} \text { free. }\end{array}$ \\
\hline 41 & $\begin{array}{l}\text { Griess reagent working } \\
\text { solution is not translucid }\end{array}$ & $\begin{array}{l}\text { Issue with the storage or } \\
\text { the preparation of the } \\
\text { stock or aliquoted } \\
\text { reagent }\end{array}$ & \multicolumn{2}{|c|}{$\begin{array}{l}\text { If the Griess reagent working solution turns } \\
\text { pink, it indicates a previous contamination of } \\
\text { your reagent. Discard and take a new } \\
\text { aliquoted working solution. }\end{array}$} \\
\hline 73 & Insufficient pellet & Low cell density & $\begin{array}{l}\text { (I) } \\
\text { (II) } \\
\text { (III) }\end{array}$ & $\begin{array}{l}\text { Plate as many } 24 \text {-well plates as } \\
\text { necessary to achieve the desired } \\
\text { number of cells. } \\
\text { Avoid prolonged exposure to trypsin. } \\
\text { Make sure the cells are not dead from } \\
\text { a lethal dose, if this the case adjust the } \\
\text { parameters (gas flow, distance or } \\
\text { treatment time) in steps } 9,11 \text { or } 12 \text {, } \\
\text { respectively. }\end{array}$ \\
\hline
\end{tabular}

753 Steps 1-2 Cell plating prior to treatment: 60 min plus overnight culture.

754 Steps 3-13 option a, Direct method (CAP) on cell culture: 40 min plus $\sim 1$ week growing time, and 755 overnight plus $2 \mathrm{~h}$ incubation time.

756 Steps 3-13 option b, Indirect method (PCM) on cell culture: 45 min plus 1 week growing time 757 and overnight plus $2 \mathrm{~h}$ incubation time.

758 Steps 14-21, WST-1 assay 1.5-3 h, depending on incubation time.

759 Steps 22-28: Total ROS: 45 min, plus PCM production

760 Steps 29-40, $\mathrm{H}_{2} \mathrm{O}_{2}$ quantification: $\sim 75 \mathrm{~min}$ plus $\mathrm{PCM}$ production

761 Steps 41-50, $\mathrm{NO}_{2}^{-}$quantification: $\sim 75$ min plus PCM production

762 Steps 51-65, $\mathrm{NO}_{3}{ }^{-}$quantification: $\sim 75 \mathrm{~min}$, plus $\mathrm{PCM}$ production

763 Steps 66-73, Trypsinization of cells: 30 min plus time required for downstream assays. 
Box 1:PCM Treatment of cells growing in different culture formats : 75 min plus time required for downstream assays.

\section{ANTICIPATED RESULTS}

This protocol can be applied to cells growing on different sized culture plates, and is thus scalable. However, the same well plate size should be used consistently throughout an experiment (ie. when investigating RONS, Cytotoxicity, and cell signaling simultaneously) as the well size can impact results. This is clear when comparing the cytotoxic effect obtained by CAP and PCM on U-2 OS cells grown on different plates (Figure 8), following the scheme in Figure 4 and the adaptations shown in Box 1 regarding cell density, plate format and liquid volume.

a

U-2 OS

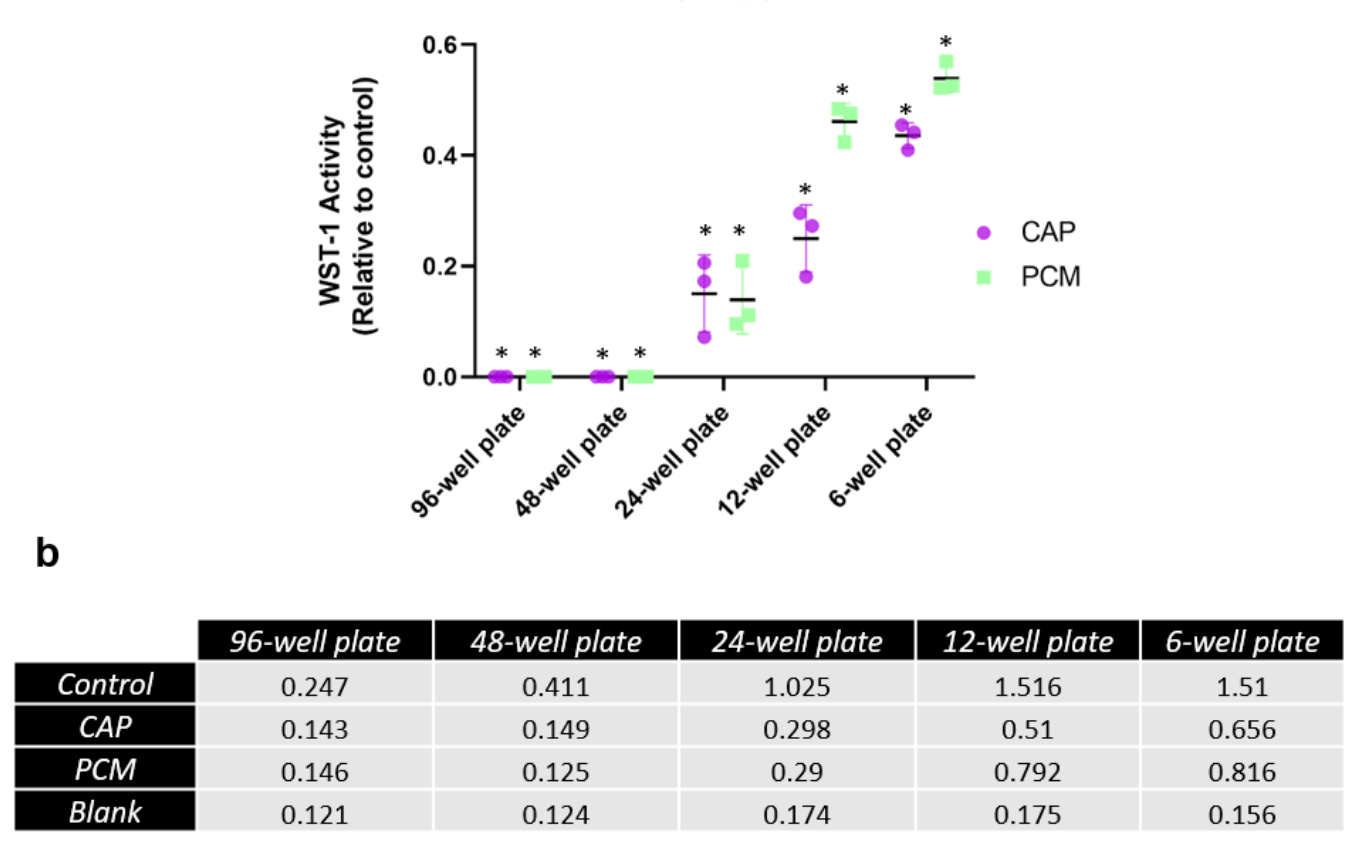

Figure 8: Cell cytotoxicity assay applied to different dish sizes. a) WST-1 assay 24 h posttreatment using a gas flow of $3 \mathrm{~L} / \mathrm{min}$ and $10 \mathrm{~mm}$ distance for $30 \mathrm{~s}$ showing that well plate affects CAP or PCM toxicity. Cell viability is expressed relative to untreated controls and corresponds to the mean and standard deviation of three independent experiments $\left({ }^{*} p<0.001\right.$; two-sided Student's t-test). b) Indicative absorbance values of WST-1 obtained in the control, treatments and blanks of the plate sizes shown.

In this example, smaller well plates containing less cells are more sensitive to CAP or PCM. This is as expected as the number of cells limits the cytotoxic effect of PCM or CAP ${ }^{27}$ and the size of the well and the volume of liquid modify the amount of RONS produced ${ }^{19}$. We therefore recommend using a minimum plate size of 24 -well plate to perform this complete protocol. 
a

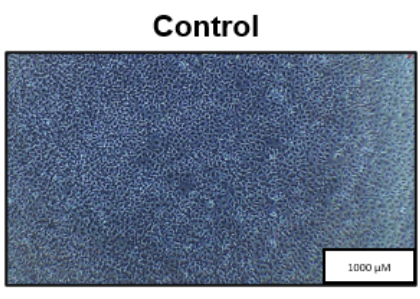

b

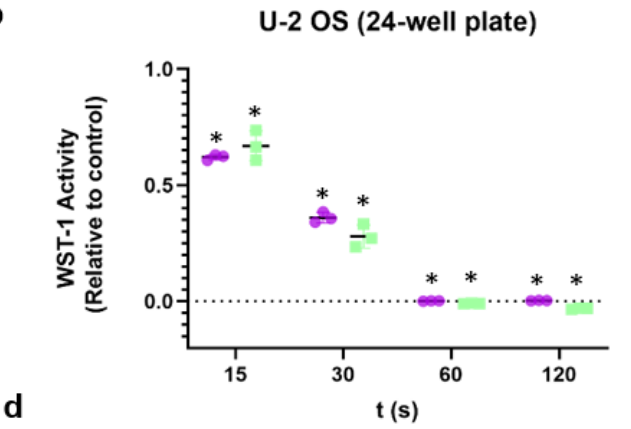

CAP

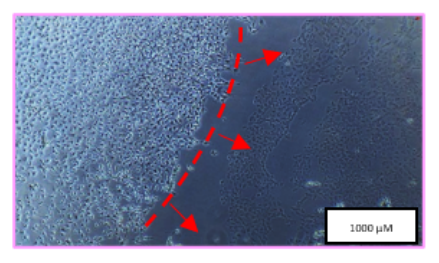

c

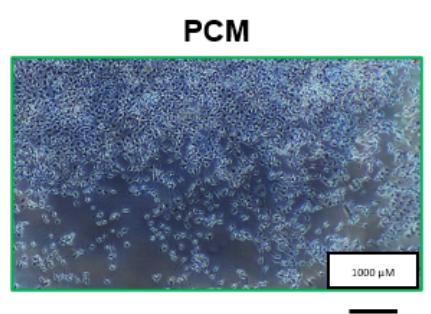

(24-well plate)

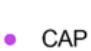

PCM

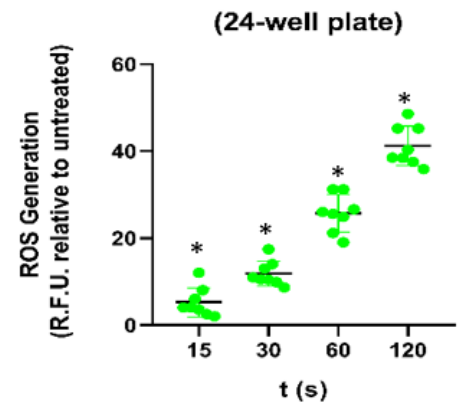

(24-well plate)

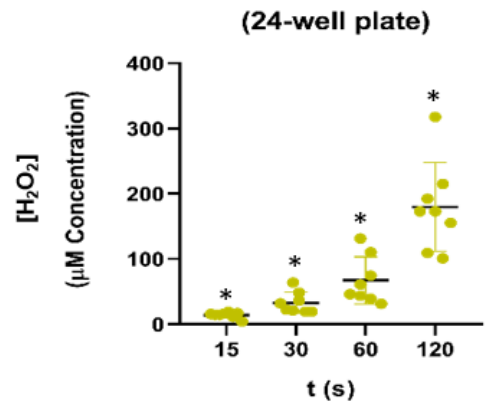

(24-well plate)

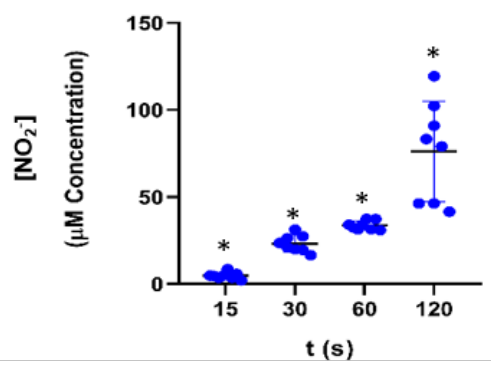

e

\begin{tabular}{|c|c|c|}
\hline & \multicolumn{2}{|c|}{ Absorbance $540 \mathrm{~nm}$} \\
\hline Nitrites $(\mu \mathrm{M})$ & $\mathrm{R} \# 1$ & $\mathrm{R} \# 2$ \\
\hline 0 & 0.044 & 0.045 \\
\hline 2.19 & 0.05 & 0.055 \\
\hline 4.38 & 0.065 & 0.065 \\
\hline 8.75 & 0.087 & 0.085 \\
\hline 17.5 & 0.123 & 0.122 \\
\hline 35 & 0.199 & 0.196 \\
\hline 70 & 0.368 & 0.385 \\
\hline 140 & 0.603 & 0.562 \\
\hline
\end{tabular}$$
140
$$

Fluorescence 560/590 nm

\begin{tabular}{|c|c|c|} 
Hydrogen Peroxides $(\mu \mathrm{M})$ & R\#1 & R\#2 \\
\hline 0 & 300494 & 331473 \\
\hline 0.5 & 413127 & 391278 \\
\hline 1 & 467212 & 432233 \\
\hline 2 & 550219 & 532855 \\
\hline 3 & 669262 & 642762 \\
\hline 4 & 808288 & 757036 \\
\hline 5 & 974012 & 898804 \\
\hline
\end{tabular}

Figure 9: Typical results following treatments in 24 -well plates. $30 \times 10^{3} \mathrm{U}-2$ OS cells/well were cultured in a 24-well plate and treated by CAP or PCM for 30 seconds using a gas flow of $3 \mathrm{~L} / \mathrm{min}$ and $10 \mathrm{~mm}$ distance. These parameters were selected based on previous works ${ }^{14,16-19}$. Representative images taken with an optical microscope $24 \mathrm{~h}$ post-treatment. The red arrow indicates the cell culture region directly exposed to CAP. Scale bar $=1000 \mu \mathrm{M}$. b) Cytotoxicity results following treatment of U-2 OS cells with CAP or PCM for 15, 30, 60 and $120 \mathrm{~s}$, using WST-1 assay $24 \mathrm{~h}$ post-treatment. Cell viability is expressed relative to untreated cells and corresponds to the mean and standard deviation of three independent experiments. c) Total ROS

787 (fluorescence relative to untreated DMEM-Pyr) and of $\mathrm{H}_{2} \mathrm{O}_{2}$ and $\mathrm{NO}_{2}^{-}$, together with d) table showing the fluorescence and e) table showing the absorbance values obtained from the 
calibration lines of $\left[\mathrm{H}_{2} \mathrm{O}_{2}\right]$ and $\left[\mathrm{NO}_{2}^{-}\right]$. c, $\mathrm{d}$ and e show results from eight independent experiments

$790 \quad(* \mathrm{p}<0.001 ;$ two-sided Student's t-test compared to untreated $)$

791 CAP allows localized treatment of cells and tumors, while PCM may allow access to wider areas, 792 as shown by visualization of U-2 OS cells in treated wells $4 \mathrm{~h}$ after treatment using a microscope 793 (Figure 9a). These images were obtained following direct exposure to CAP (Steps 3-12 option 794 A) or PCM (Steps (Steps 3-12 option B), following the workflow in Figure 1. Following CAP 795 treatment, the area directly exposed to the plasma jet contains very few cells (Figure 9a, center), 796 whilst following PCM treatment cells are more homogeneously affected, with a lower number 797 than in the control culture and cells impacted across whole surface of the well (Figure 9a, right).

798 As anticipated, cell viability was inhibited in a treatment time-dependent manner, and for this 799 particular configuration and device, without significant differences between CAP or PCM (Figure 800 9b). This was determined by WST-1 $24 \mathrm{~h}$ post-treatment (Steps 14-21).

801 The involvement of RONS generated by plasmas in cell culture media in the anticancer effects of $802 \mathrm{PCM}$ has been reported in many studies, with particular emphasis on the role of $\mathrm{H}_{2} \mathrm{O}_{2}$ and $\mathrm{NO}_{2}{ }^{-}$, 803 among other species ${ }^{22,29}$. The concentration of RONS in PCM in general increases with plasma 804 treatment time, as shown here (Figure $9 \mathrm{c}, \mathrm{d}$, e) for $\mathrm{H}_{2} \mathrm{O}_{2}, \mathrm{NO}_{2}{ }^{-}$and total ROS. The protocol can 805 be used to measure $\mathrm{NO}_{3}{ }^{-}$but using the conditions shown here, nitrates were not detectable, so 806 results are not shown.

807 Total ROS (Figure 9c) were determined following steps 22-28. Similarly, the concentration of 808 hydrogen peroxide was determined by Amplex ${ }^{\mathrm{TM}}$ Red Hydrogen/HRP Peroxide following steps 809 29-40. Since the highest concentration of $\mathrm{H}_{2} \mathrm{O}_{2}$ able to be detected reliably by this reagent is 810 around $5 \mu \mathrm{M}$, dilution of PCM was necessary. PCM was thus diluted 10 (for PCM treatment times 811 or 15 and $30 \mathrm{~s}$ ) or 50 (for PCM treatment times of 60 and $120 \mathrm{~s}$ ) times in DMEM without Pyruvate 812 before adding the reagent, based on our previous experience with this method ${ }^{14}$ and measured by 813 fluorescence. Concentrations of $\mathrm{H}_{2} \mathrm{O}_{2}$ in PCM generated by plasma treatment were obtained from 814 fluorescence values using a calibration curve as shown in the table included in Figure $9 \mathrm{~d} . \mathrm{NO}_{2}{ }^{-}$in 815 PCM was quantified using Griess reagent ${ }^{28}$ following steps 41-50 and lower concentrations were 816 found than for $\mathrm{H}_{2} \mathrm{O}_{2}$, which is often the case, and greatly depends on the treatment conditions. 817 The concentration of $\mathrm{NO}_{2}{ }^{-}$in each sample was determined from the absorbance values (Figure 818 9e) by using a calibration curve made from $\mathrm{NaNO}_{2}$ diluted in DMEM-Pyr. In the conditions 819 employed here an equilibrated cocktail of both reactive species $\left(\mathrm{H}_{2} \mathrm{O}_{2}\right.$ and $\left.\mathrm{NO}_{2}{ }^{-}\right)$was obtained ${ }^{14}$ 820 except following $120 \mathrm{~s}$ of treatment, which resulted in the concentration of $\mathrm{H}_{2} \mathrm{O}_{2}$ overwhelming 821 that of $\mathrm{NO}_{2}^{-}$(Figure $\left.9 \mathrm{~d}, \mathrm{e}\right)$. 
Previous works have demonstrated the effects on cell signaling using CAP or PCM ${ }^{30-37}$. An advantage of this protocol is that it allows cell signaling following PCM or CAP treatments to be compared, using the same application parameters.

a

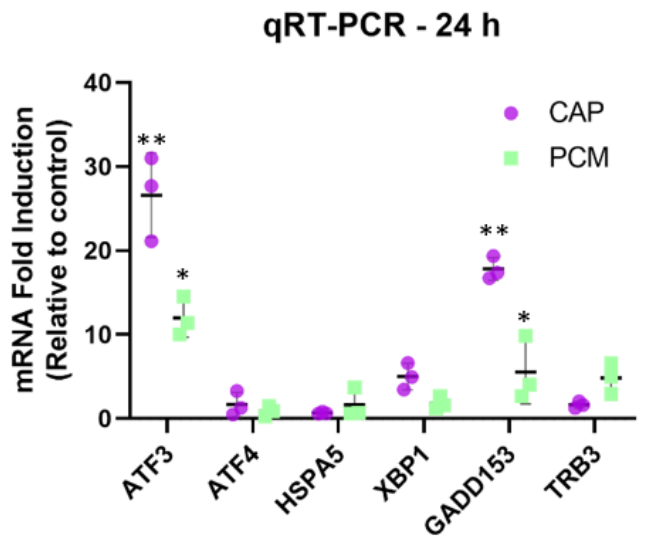

b U-2 OS (4 h Post-treatment)

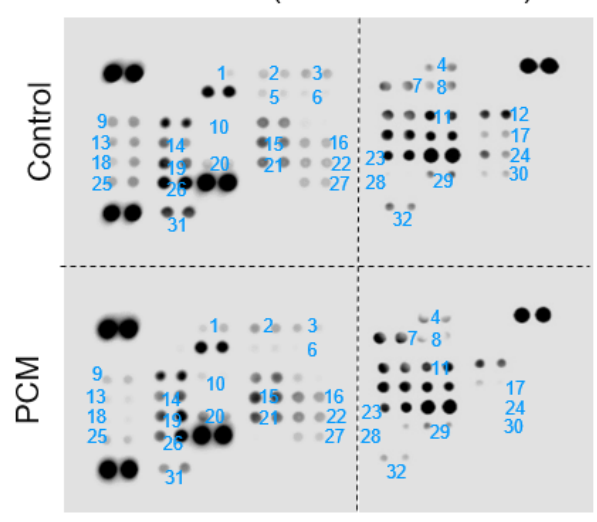

c

U-2 OS Cells - Control vs. 60 s PCM

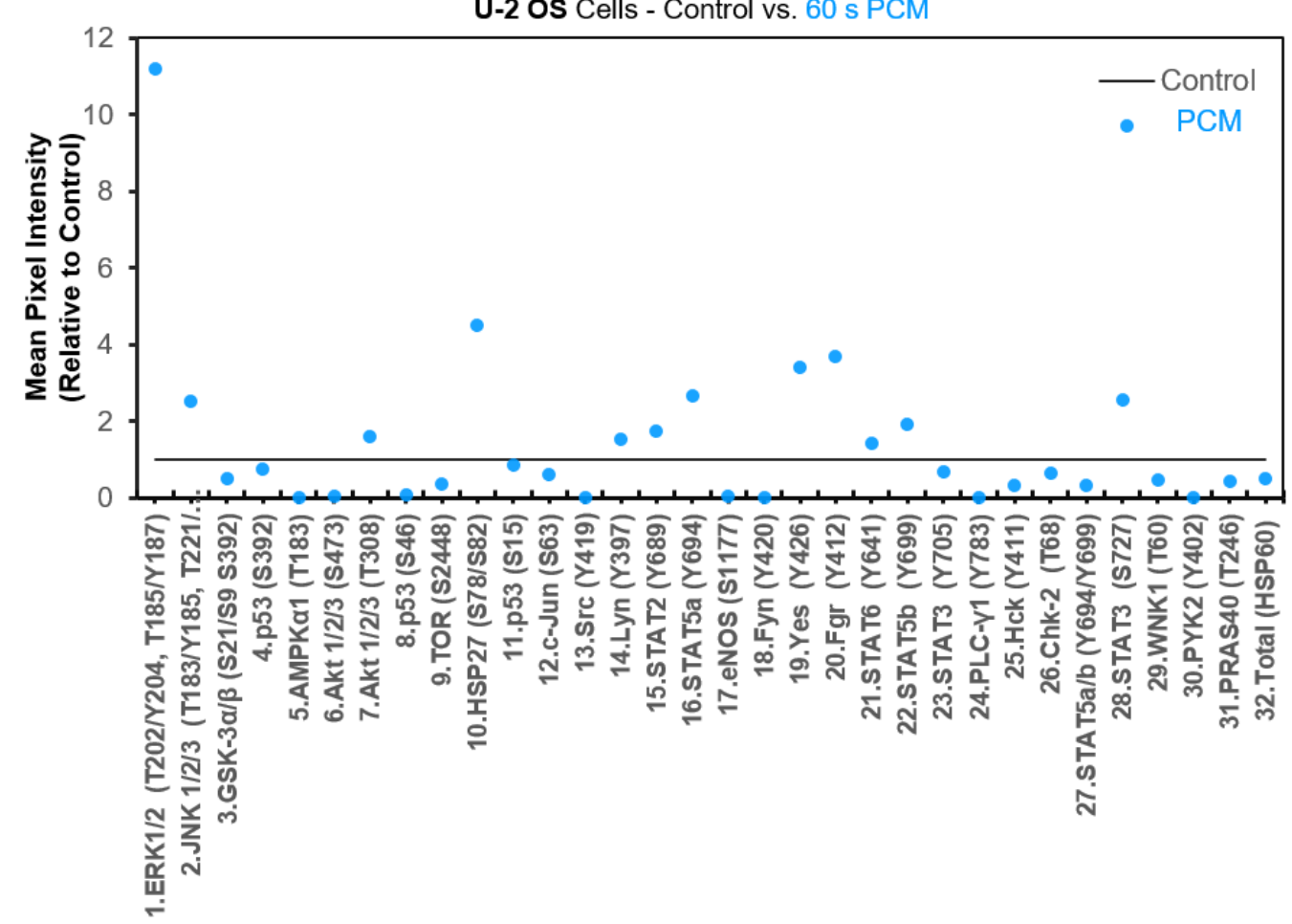

826 Figure 10: Analysis of components known to be involved in cell signaling. a) U2-OS human OS cells were exposed to 60 seconds of CAP or PCM in three independent 24-well plates. Treated cells from 24 wells were pooled together and pelleted and the expression of indicated genes measured $24 \mathrm{~h}$ post-treatment by qRT-PCR. Data are presented as mean, $\mathrm{n}=3$. Error bars represent the SD, and asterisks indicate statistically significant differences relativized to control (untreated). (*p $<0.005 ;{ }^{*} \mathrm{p}<0.001$; two-sided Student's t-test). b) Phospho-kinase antibody array showing the phosphorylation/activation status of 32/45 proteins selected after the same 
treatment with control (top) or indirect treatment (PCM) (bottom). c) Example of a result of analysis of the phosphor-kinase antibody array, where selected spots were digitized, and mean pixel intensity is presented as line (control) or blue markers (PCM). Numbers indicate the reference spot of selected proteins.

We carried out qRT-PCR (Supplementary Methods 1) to look at differences in gene expression following CAP and PCM using $60 \mathrm{~s}$ in U-2 OS cells $24 \mathrm{~h}$ post-treatment. We obtained sufficient cells by harvesting a whole 24-well cell seeded plate treated by CAP or PCM for each replicate $(n=3$ plates separately). Yield of treated cells will depend on the cell line employed. In U-2 OS both CAP and PCM treatment resulted in an up-regulation of ATF3, splicing-XBP1, GADD153, and TRB3, with significant differences between treatments with respect to control (Figure 10a).

CAP and PCM treatment did have differing effects on some gene expression profiles. These effects were not a consequence of differences in cell toxicity between CAP or PCM, as no significant differences are seen following $30 \mathrm{~s}$ treatment (Figure 9b). This indicates that the treatments act via different mechanisms.

Molecular analysis following PCM treatment has been applied previously ${ }^{14}$. Figure $10 \mathrm{~b}$ and c show results from $750 \times 10^{3}$ cells cultured in a $100 \mathrm{~mm}^{2}$ petri dish and treated with $8 \mathrm{~mL}$ of PCM - 60 s (Box 1), followed by a 4-hour recovery before lysis. Cell lysates applied to a Profiler Human Phospho-kinase Array to analyze the changes in the kinase phosphorylation profile of U-2 OS cells after the treatment with PCM (Figure 10 b, c) (Supplementary Methods 2). Differential regulation was seen in 32 of the 45 proteins analyzed (Figure $10 \mathrm{~b}, \mathrm{c}$ ). In a previous study with SaOS-2 cells we obtained similar cell signaling by PCM ${ }^{14}$. PCM produces increased phosphorylation of 12/32 kinases: ERK1/2 (T202/Y204), JNK 1/2/3 (T183/Y185, T221/ Y223), AKT 1/2/3 (T308), HSP27 (S78/S82), Lyn (Y397), STAT2 (Y689), STAT5a (Y694), Yes (Y426), Fgr (Y412), STAT6 (Y641), STAT5b (Y699), and STAT3 (S727). However PCM induces a general inhibitory effect on 20/32 kinases : GSK-3 $\alpha / \beta$ (S21/S9), p53 (S392), AMPK $\alpha 1$ (T183), Akt 1/2/3 (S473), p53 (S46), TOR (S2448), p53 (S15), c-JUN (S63), Src (Y419), eNOS (S1177), Fyn (Y420), STAT3 (Y705), PLC- $\gamma 1$ (Y783), Hck (Y411), Chk-2 (T68), STAT5a/b (Y694/Y699), WNK1 (T60), PYK2 (Y402), PRAS40 (T246) and total protein HSP60.

\section{Data Availability statement}

Source data is available for figures 8-10 at: https://upcommons.upc.edu/handle/2117/330395

\section{Supplementary Information:}


Supplementary Table 1. Influence of modifying different cold atmospheric plasma jet parameters

866 (type of gas, gas flow) or of the liquid treated (volume, type: cell culture media, saline solutions,

867 etc.) on the biological response (cell viability) of a variety of cell lines. Summary of results 868 reported in the literature.

869 Supplementary Method 1. RNA extraction and RT-PCR analysis of CAP or PCM-treated U-2 OS 870 cells.

871 Supplementary Method 2. Human Phospho-Kinase Array

\section{Acknowledgements}

This project has received funding from the European Research Council (ERC) under the European Union's Horizon 2020 research and innovation programme (grant

\section{Competing interests}

880 The authors declare no competing interests.

\section{Authors contributions statement}

JT and CL contributed in the acquisition, analysis and interpretation of data, optimization of the protocol, and writing of the work. FT contributed to acquisition and analysis of data, and to revising it. MPG contributed to writing, discussing and revising the work. CC conceived the work, contributed to writing and substantively revising it.

\section{REFERENCES}

8881 Lis, K. A. et al. Inactivation of multidrug-resistant pathogens and Yersinia enterocolitica with cold atmospheric-pressure plasma on stainless-steel surfaces. Int $J$ Antimicrob Agents 52, 811-818, doi:10.1016/j.ijantimicag.2018.08.023 (2018).

2 Brun, P. et al. Antibacterial efficacy and mechanisms of action of low power atmospheric pressure cold plasma: membrane permeability, biofilm penetration and antimicrobial sensitization. J Appl Microbiol 125, 398-408, doi:10.1111/jam.13780 (2018).

3 Yang, Y. et al. A novel cold atmospheric pressure air plasma jet for peri-implantitis treatment: An in vitro study. Dent Mater J 37, 157-166, doi:10.4012/dmj.2017-030 (2018).

4 Klämpfl, T. G. et al. Decontamination of Nosocomial Bacteria Including Clostridium difficile Spores on Dry Inanimate Surface by Cold Atmospheric Plasma. Plasma Processes and Polymers 11, 974-984, doi:10.1002/ppap.201400080 (2014). 
9005 Daeschlein, G. et al. Skin and wound decontamination of multidrug-resistant bacteria by cold atmospheric plasma coagulation. $J$ Dtsch Dermatol Ges 13, 143-150, doi:10.1111/ddg.12559 (2015).

6 Arndt, S., Unger, P., Berneburg, M., Bosserhoff, A. K. \& Karrer, S. Cold atmospheric plasma (CAP) activates angiogenesis-related molecules in skin keratinocytes, fibroblasts and endothelial cells and improves wound angiogenesis in an autocrine and paracrine mode. J Dermatol Sci 89, 181-190, doi:10.1016/j.jdermsci.2017.11.008 (2018).

7 Duchesne, C., Banzet, S., Lataillade, J. J., Rousseau, A. \& Frescaline, N. Cold atmospheric plasma modulates endothelial nitric oxide synthase signalling and enhances burn wound neovascularisation. J Pathol 249, 368-380, doi:10.1002/path.5323 (2019).

8 Nomura, Y. et al. Investigation of blood coagulation effect of nonthermal multigas plasma jet in vitro and in vivo. $J$ Surg Res 219, 302-309, doi:10.1016/j.jss.2017.06.055 (2017).

9 Schuster, M. et al. Visible tumor surface response to physical plasma and apoptotic cell kill in head and neck cancer. $J$ Craniomaxillofac Surg 44, 1445-1452, doi:10.1016/j.jcms.2016.07.001 (2016).

10 Isbary, G. et al. Cold atmospheric plasma for local infection control and subsequent pain reduction in a patient with chronic post-operative ear infection. New Microbes New Infect 1, 41-43, doi:10.1002/2052-2975.19 (2013).

11 Heinlin, J. et al. Plasma applications in medicine with a special focus on dermatology. $J$ Eur Acad Dermatol Venereol 25, 1-11, doi:10.1111/j.1468-3083.2010.03702.x (2011).

12 Dubuc, A. et al. Use of cold-atmospheric plasma in oncology: a concise systematic review. Ther Adv Med Oncol 10, 1758835918786475, doi:10.1177/1758835918786475 (2018).

13 Bauer, G., Sersenova, D., Graves, D. B. \& Machala, Z. Cold Atmospheric Plasma and Plasma-Activated Medium Trigger RONS-Based Tumor Cell Apoptosis. Sci Rep 9, 14210, doi:10.1038/s41598-019-50291-0 (2019).

14 Tornin, J. et al. Pyruvate Plays a Main Role in the Antitumoral Selectivity of Cold Atmospheric Plasma in Osteosarcoma. Sci Rep 9, 10681, doi:10.1038/s41598-01947128-1 (2019).

15 Cheng, X. et al. The effect of tuning cold plasma composition on glioblastoma cell viability. PLoS One 9, e98652, doi:10.1371/journal.pone.0098652 (2014).

16 Canal, C. et al. Plasma-induced selectivity in bone cancer cells death. Free Radic Biol Med 110, 72-80, doi:10.1016/j.freeradbiomed.2017.05.023 (2017).

17 Labay, C., Hamouda, I., Tampieri, F., Ginebra, M. P. \& Canal, C. Production of reactive species in alginate hydrogels for cold atmospheric plasma-based therapies. Sci Rep $\mathbf{9}$, 16160, doi:10.1038/s41598-019-52673-w (2019).

18 Mateu-Sanz, M. et al. Cold Plasma-Treated Ringer's Saline: A Weapon to Target Osteosarcoma. Cancers (Basel) 12, doi:10.3390/cancers12010227 (2020).

19 Khlyustova, A., Labay, C., Machala, Z., Ginebra, M.-P. \& Canal, C. Important parameters in plasma jets for the production of RONS in liquids for plasma medicine: A brief review. Frontiers of Chemical Science and Engineering 13, 238-252, doi:10.1007/s11705-019-1801-8 (2019).

20 Tanaka, H. et al. Plasma-Activated Medium Selectively Kills Glioblastoma Brain Tumor Cells by Down-Regulating a Survival Signaling Molecule, AKT Kinase. 1, 265-277, doi:10.1615/PlasmaMed.2012006275 (2011).

21 Tanaka, H. et al. Non-thermal atmospheric pressure plasma activates lactate in Ringer's solution for anti-tumor effects. Sci Rep 6, 36282, doi:10.1038/srep36282 (2016).

22 Girard, P. M. et al. Synergistic Effect of H2O2 and NO2 in Cell Death Induced by Cold Atmospheric He Plasma. Sci Rep 6, 29098, doi:10.1038/srep29098 (2016).

23 Schmidt, A. et al. Cold Physical Plasma Modulates p53 and Mitogen-Activated Protein Kinase Signaling in Keratinocytes. Oxid Med Cell Longev 2019, 7017363, doi:10.1155/2019/7017363 (2019).

24 Yan, D. et al. The Specific Vulnerabilities of Cancer Cells to the Cold Atmospheric Plasma-Stimulated Solutions. Sci Rep 7, 4479, doi:10.1038/s41598-017-04770-x (2017). 
25 Tornín, J., Villasante, A., Solé-Martí, X., Ginebra, M.-P. \& Canal, C. Osteosarcoma Tissue-Engineered Model Challenges Oxidative Stress Therapy Revealing Promoted Cancer Stem Cell Properties. Free Radical Biology and Medicine, doi:https://doi.org/10.1016/j.freeradbiomed.2020.12.437 (2021).

26 Bauer, G. Targeting Protective Catalase of Tumor Cells with Cold Atmospheric PlasmaActivated Medium (PAM). Anti-Cancer Agents in Medicinal Chemistry 18, 784-804, doi:10.2174/1871520617666170801103708 (2018).

27 Yan, D. et al. The Strong Cell-based Hydrogen Peroxide Generation Triggered by Cold Atmospheric Plasma. Sci Rep 7, 10831, doi:10.1038/s41598-017-11480-x (2017).

28 Guevara, I. et al. Determination of nitrite/nitrate in human biological material by the simple Griess reaction. Clinica chimica acta; international journal of clinical chemistry 274, 177-188 (1998).

29 Kim, S. J. \& Chung, T. H. Cold atmospheric plasma jet-generated RONS and their selective effects on normal and carcinoma cells. Sci Rep 6, 20332, doi:10.1038/srep20332 (2016).

30 Akter, M., Jangra, A., Choi, S. A., Choi, E. H. \& Han, I. Non-Thermal Atmospheric Pressure Bio-Compatible Plasma Stimulates Apoptosis via p38/MAPK Mechanism in U87 Malignant Glioblastoma. Cancers (Basel) 12, doi:10.3390/cancers12010245 (2020).

31 Bundscherer, L. et al. Impact of non-thermal plasma treatment on MAPK signaling pathways of human immune cell lines. Immunobiology 218, 1248-1255, doi:https://doi.org/10.1016/j.imbio.2013.04.015 (2013).

32 Kang, S. U. et al. Nonthermal plasma induces head and neck cancer cell death: the potential involvement of mitogen-activated protein kinase-dependent mitochondrial reactive oxygen species. Cell Death Dis 5, e1056, doi:10.1038/cddis.2014.33 (2014).

33 Kaushik, N. et al. Responses of solid tumor cells in DMEM to reactive oxygen species generated by non-thermal plasma and chemically induced ROS systems. Sci Rep 5, 8587, doi:10.1038/srep08587 (2015).

34 Xiang, L., Xu, X., Zhang, S., Cai, D. \& Dai, X. Cold atmospheric plasma conveys selectivity on triple negative breast cancer cells both in vitro and in vivo. Free Radical Biology and Medicine 124, 205-213, doi:https://doi.org/10.1016/j.freeradbiomed.2018.06.001 (2018).

35 Schmidt, A. et al. Role of Ambient Gas Composition on Cold Physical Plasma-Elicited Cell Signaling in Keratinocytes. Biophys J 112, 2397-2407, doi:10.1016/j.bpj.2017.04.030 (2017).

36 Bekeschus, S. et al. Risk Assessment of kINPen Plasma Treatment of Four Human Pancreatic Cancer Cell Lines with Respect to Metastasis. Cancers (Basel) 11, doi:10.3390/cancers11091237 (2019).

37 Bekeschus, S. et al. Neutrophil extracellular trap formation is elicited in response to cold physical plasma. Journal of leukocyte biology 100, 791-799, doi:10.1189/jlb.3A0415165RR (2016). 